\title{
任意分布の荷重を受ける異方性だ円筒の解析
}

\author{
種 健*1, 佐々木 徹*2, 田淵 大介*1, 内田 武*1, 浜野 浩幹*3
}

\section{Analysis for an anisotropic hollow cylindroid subjected to arbitrary loadings}

\author{
Takeshi TANE $^{* 1}$, Toru SASAKI ${ }^{* 2}$, Daisuke TABUCHI ${ }^{* 1}$, Takeshi UCHIDA ${ }^{* 1}$ and Hiroki HAMANO*3 \\ ${ }^{* 1}$ Machine Systems Engineering Course, Department of Creative Engineering, National Institute of Technology, Kitakyushu College \\ 5-20-1 Shii, Kokuraminami-ku, Kitakyushu-shi, Fukuoka 802-0985, Japan \\ ${ }^{* 2}$ Department of Mechanical Engineering, National Institute of Technology, Nagaoka College \\ 888 Nishikatakai, Nagaoka-shi, Niigata 940-8532, Japan \\ ${ }^{* 3}$ National Institute of Technology, Matsue College \\ 14-4 Nishiikuma-cho, Matsue-shi, Shimane 690-8518, Japan
}

Received 24 November 2015

\begin{abstract}
In this paper, the solution for the hollow cylindroid is analytically derived under two assumptions that (1) the cylindroid is consist of various anisotropic elastic material and (2) only both sides of the hollow cylindroid are subjected to arbitrary load, which will be expanded to complex form of Fourier series with period $2 \pi$. To simplify an analysis, mapping function, which is mapped elliptical boundaries of the cylindroid to unit circle, and complex stress functions proposed by S. G. Lekhnitskii are introduced. These stress functions have undetermined coefficients, however, these coefficients can be determined by taking into account the boundary conditions for resultant stresses at both sides of the hollow cylindroid. In particular, undetermined coefficients in stress functions will be determined by comparing with complex Fourier coefficients for those resultant stresses. In the case of isotropic cylindroid, analytical solution for similar problem was already derived, however, there is one limit of application. This limit is related to the cross-sectional shape of hollow cylindroid. That is, if both sides of the hollow cylindroid did not have a same focus of an ellipse, analytical solution for isotropic case was not able to derive. On the other hand, the solution derived from this study does not have such a limit. So some numerical examples are shown by some figures and tables not only anisotropic case but also isotropic case.
\end{abstract}

Key words : Anisotropy, Hollow cylindroid, Two-dimensional elastic theory, Constraint release technique, Creave test, Composite material

\section{1. 緒言}

航空・宇宙分野では, 二酸化炭素排出の抑制と燃費向上 (軽量化) の観点から, 航空機やロケットの機体に CFRP をはじめとする複合材料が多く用いられている。一般旅客機の場合，航空機 2 次部材としての利用により十分な 安全性が確認されつつあること, 安価で安定的な複合材料の供給が可能となったことなどから, 全質量に占める 複合材料の割合が現在では 50\%に達する機体も登場し，運用開始されている.

この複合材料は，個々の材料の持つ利点によって互いの欠点を補うものであり，それまでの材料にない優れた 機械的性質を付与寸ることを可能としている．例えば先の CFRP は，プラスチックの軽さと炭素䋊維の高強度を 併せ持たせることにより，比強度は高張力鋼材の 10 倍以上を実現している.しかし，炭素繊維の配向によっては CFRP の変形は方向依存性（力学的異方性）を示し，工業用材料としての取り扱いに十分な注意を要する.

また，岩盤やコンクリートなどのぜい性材料の引張強度は割裂試験（間接引張試験法）により算定され，その 試験方法は地盤工学会基準 JGS 2251，日本工業規格 JIS A 1113 において定められている．引張強度 $\sigma_{t}[\mathrm{MPa}]$ は,

No.15-00627 [DOI:10.1299/transjsme.15-00627], J-STAGE Advance Publication date : 24 February, 2016

*1 正員, 北九州工業高等専門学校生産デザイン工学科機械創造システムコース（テ802-0985 福岡県北九州市小倉南区志井 5-20-1）

*2 正員，長岡工業高等専門学校機械工学科（广940-8532 新潟県長岡市西片貝 888)

*3 正員，松江工業高等専門学校（一690-8518 島根県松江市西生馬町 14-4）

E-mail of corresponding author: tane@ kct.ac.jp 
材料を等方性とする仮定の下に, $\sigma_{t}=2 P / \pi D L(P$ : 圧縮集中荷重 $[\mathrm{N}], D$ : 試験片直径 $[\mathrm{mm}], L$ : 試験片長さ $[\mathrm{mm}])$ で算定されている。しかし, この引張強度には方向依存性が見られる場合も多く, 稲田花崗岩を対象とした実験 では，もっとも割れやすい面の引張強度が他 2 面の $1 / 2$ ほどしかないとの報告もある（林他，2003）。これはすな わち，材料を等方性とする仮定にもはや限界があることを示すものである.

複合材料などの人工材料，岩盤などの天然材料，いずれの場合にせよ，材料の異方性弾性定数の同定技術の規 格化・高精度化（奈良，金子，2003）を背景に，この材料異方性を考慮して形ある物体に様々な力学的負荷が作 用する場合の解析解（応力や変位の分布）を求めることは, CAE 技術の普及・高度化に伴い，より実物に近い形 状を手軽に検討できるようになってきたからこそ重要であるとの指摘がなされている（中曽根，2014）.

2 次元弾性理論において考慮する 2 種の問題（面内問題および面外せん断問題）が相互に影響（連成）するよ うな，最も一般的な異方性弾性材料を対象とした解析的研究としては，遠方場一様荷重を受ける孔を有する無限 体 (丹羽他, 1970a, 丹羽他, 1970b), この孔の周囲に補強層や緩和層が存在する場合 (種他, 2004, 種他, 2005), 任意荷重を側面に受けるだ円柱（種他，2012）などが挙げられる.

一方，2 種の問題が連成しない異方性弾性材料（以下，「異方性弾性材料の特別な場合」と表記）については, だ円孔を有する平板曲げの問題（高野他，2001）, 半無限板の面内問題（田中他，1992，田中他，1993）, 面外せ ん断問題（志村他，2002），任意荷重を受けるだ円柱（川久保他，1996），任意荷重を受けるだ円リング（堤，平 島，1997），極異方性を示すリング，円孔を有する無限体の解（中山他，2003）などがある．また，CFRPの用途 拡大を背景に, 異方性円筒殼の軸圧縮・㸚じりおよびこれらの複合荷重問題を検討した例もある（Nemeth and Schultz, 2012, 高野, 2013, 高野, 2014).

しかしながら，面内問題と面外せん断問題が互いに連成する一般的な異方性弾性材料について，任意の荷重を 側面に受けるだ円リング（だ円筒）を解析した例は見当たらない，そこで，本研究では 2 次元弾性理論をベース に, 任意荷重を周期 $2 \pi$ の複素フーリエ級数に展開して解を求めるとともに，幾つかの数值計算例を示す.

本報告をはじめとして, 最も一般的な異方性弾性材料の解析解は, 対応原理により一般的な異方性粘弾性材料 へと拡張でき（桜井，1971）, また，基礎方程式の類似性により，圧電性を有する異方性弾性材料の特別な場合に 応用が可能である (佐々木他, 2005)。 また, 弾性コンプライアンスの特別な場合を取り上げれば, 等方性弾性材 料や異方性弾性材料の特別な場合の解も求めることができるため, その成果の応用範囲は多岐にわたる.

\section{2. 問題設定および基礎方程式}

本論文では, 図 1 に示寸ように長軸 $a_{1}$, 短軸 $b_{1}$ のだ円柱の内部に長軸 $a_{2}$, 短軸 $b_{2}$ のだ円孔を持つ, 一般的な 異方性弾性挙動を示すだ円筒の解を導く，そのために，断面の長軸，短軸の方向をそれぞれ $x, y$ 軸，これら 2 軸 に垂直な方向（母線方向）を $z$ 軸と寸る直交座標系 $(x, y, z)$ を考える.

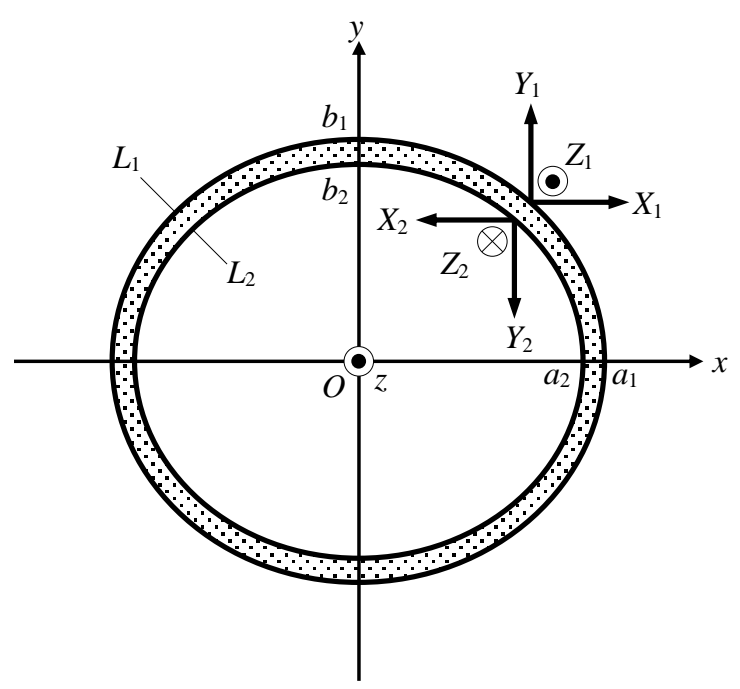

Fig. 1 Two-dimensional analytical model (elliptic cylinder subjected to arbitrary loads on its two lateral surfaces). 
Tane, Sasaki, Tabuchi, Uchida and Hamano, Transactions of the JSME (in Japanese), Vol.82, No.835 (2016)

だ円筒の側面は外側 $L_{1}$, 内側 $L_{2}$ の記号で表す. そして, これらの側面 $L_{j}$ が各軸方向の外力を受けている場合 を考える.これらの外力を記号 $X_{j}, Y_{j}$ および $Z_{j}(j=1 \sim 2)$ で表し， $z$ 軸方向に大きさが変化しないと仮定する. そ して, 両側面の外力を任意に取り扱うため, これらを周期 $2 \pi$ の複素フーリエ級数に展開して解を導く（後述）.

\section{$2 \cdot 1$ 基礎方程式}

2 次元弾性理論における基礎方程式は,

(1) 図 1 の $z$ 軸方向（だ円筒の母線方向）に応力・変位が変化しない.

(2) 外力によって生じる変形は微小である.

との仮定の下に導かれたものであり，力の釣合方程式，幾何式（ひずみ一変位関係），構成方程式 (応力ーひずみ 関係）からなる (Lekhnitskii, 1964). これらを以下に示す.

力の釣合方程式

$$
\left.\begin{array}{l}
\frac{\partial \sigma_{x}}{\partial x}+\frac{\partial \tau_{x y}}{\partial y}=0 \\
\frac{\partial \tau_{x y}}{\partial x}+\frac{\partial \sigma_{y}}{\partial y}=0 \\
\frac{\partial \tau_{x z}}{\partial x}+\frac{\partial \tau_{y z}}{\partial y}=0
\end{array}\right\}
$$

ここに， $\sigma_{j}$ は $j$ 軸方向の垂直応力， $\tau_{j k}$ は $j-k$ 平面内のせん断応力を表す.

幾何式

$$
\begin{aligned}
& \varepsilon_{x}=\frac{\partial u}{\partial x} \\
& \varepsilon_{y}=\frac{\partial v}{\partial y} \\
& \gamma_{y z}=\frac{\partial w}{\partial y} \\
& \gamma_{x z}=\frac{\partial w}{\partial x} \\
& \gamma_{x y} \frac{\partial v}{\partial x}+\frac{\partial u}{\partial y} .
\end{aligned}
$$

ここに， $\varepsilon_{j}$ は $j$ 軸方向の垂直ひずみ， $\gamma_{j k}$ は $j-k$ 平面内のせん断ひずみ. $u, v, w$ は $x, y, z$ 軸方向の変位である.

\section{構成方程式}

だ円筒の長さがその他寸法に比べ非常に小さく, 平面応力的に取り扱う場合の構成方程式は, 次式で表される.

$$
\left\{\begin{array}{l}
\varepsilon_{x} \\
\varepsilon_{y} \\
\gamma_{y z} \\
\gamma_{x z} \\
\gamma_{x y}
\end{array}\right\}=\left[\begin{array}{ccccc}
a_{11} & a_{12} & a_{14} & a_{15} & a_{16} \\
& a_{22} & a_{24} & a_{25} & a_{26} \\
& & a_{44} & a_{45} & a_{46} \\
& \text { sym. } & & a_{55} & a_{56} \\
& & & & a_{66}
\end{array}\right]\left\{\begin{array}{l}
\sigma_{x} \\
\sigma_{y} \\
\tau_{y z} \\
\tau_{x z} \\
\tau_{x y}
\end{array}\right\} .
$$

ここに $a_{j k}$ はだ円筒を構成する材料の弾性コンプライアンスである. なお，だ円筒の長さが非常に大きく，平面ひ ずみ的な取り扱い（ $\left.\varepsilon_{z}=0\right)$ をする場合には，式（3）の $a_{j k}$ の代わりに式（4）の $\beta_{j k}$ を用いる.

$$
\beta_{j k}=a_{j k}-\frac{a_{3 j} a_{k 3}}{a_{33}} .
$$

直交異方性弾性材料の場合，弾性コンプライアンスは次式となる. 


$$
\begin{aligned}
& a_{11}=1 / E_{x}, \\
& a_{12}=-v_{x y} / E_{x}=-v_{y x} / E_{y}, \\
& a_{13}=-v_{x z} / E_{x}=-v_{z x} / E_{z}, \\
& a_{22}=1 / E_{y}, \\
& a_{23}=-v_{y z} / E_{y}=-v_{z y} / E_{z}, \\
& a_{33}=1 / E_{z}, \\
& a_{44}=1 / G_{y z}, \\
& a_{55}=1 / G_{x z}, \\
& a_{66}=1 / G_{x y}, \\
& \text { other } a_{j k}=0 .
\end{aligned}
$$

ここに, $E_{j}$ は $j$ 軸方向の縦弾性係数, $G_{j k}$ は $j-k$ 平面内の横弾性係数である. また, $v_{j k}$ は $j-k$ 平面内のポアソン比 $(j$ 軸方向に引っ張られたとき，これに直交する $k$ 軸方向と $j$ 軸方向の垂直ひずみの比 $\left.v_{j k}=\left|\varepsilon_{k} / \varepsilon_{j}\right|\right)$ を表す.

\section{$2 \cdot 2$ 応力関数およびひずみの適合方程式}

式 (1) に示されているように, $x, y$ 軸方向の 2 つの釣合方程式には $x-y$ 平面内の 3 応力成分, $z$ 軸方向の $1 つ の$ 釣合方程式には $x-y$ 平面外の 2 せん断応力成分が関連する. 寸なわち, 双方で 1 つずつ応力成分が多い状態であ る. そこで, $x-y$ 平面内の応力成分に対して $F(x, y), x-y$ 平面外のせん断応力成分に対して $\psi(x, y)$ なる関数を 導入し，応力成分との関係を以下のように定義すれば，式（1）は自動的に満たされる.

$$
\left.\begin{array}{l}
\sigma_{x}=\frac{\partial^{2} F}{\partial y^{2}}, \\
\sigma_{y}=\frac{\partial^{2} F}{\partial x^{2}}, \\
\tau_{y z}=-\frac{\partial \psi}{\partial x}, \\
\tau_{x z}=\frac{\partial \psi}{\partial y}, \\
\tau_{x y}=-\frac{\partial^{2} F}{\partial x \partial y} .
\end{array}\right\}
$$

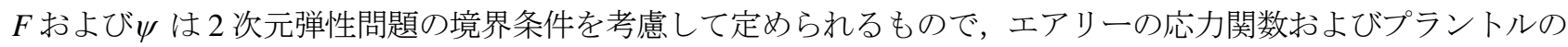
応力関数と呼ばれる（それぞれ, 面内問題, 面外せん断問題に対寸る応力関数である).

つぎに, $x-y$ 平面内の 3 ひずみ成分は 2 変位成分， $x-y$ 平面外の 2 せん断ひずみ成分は 1 変位成分で決定される (式 (2) 参照).したがって, 双方で 1 つずつ, 以下のようなひずみ成分間の制約条件が存在する. これらは, ひずみの適合方程式と呼ばれるものである.

$$
\begin{aligned}
& \frac{\partial^{2} \varepsilon_{x}}{\partial y^{2}}+\frac{\partial^{2} \varepsilon_{y}}{\partial x^{2}}-\frac{\partial^{2} \gamma_{x y}}{\partial x \partial y}=0, \\
& \frac{\partial \gamma_{x z}}{\partial y}-\frac{\partial \gamma_{y z}}{\partial x}=0
\end{aligned}
$$

\section{$2 \cdot 3$ 支配方程式}

式（7）に式（3）の構成方程式を代入し，この式にさらに式（6）に代入すると，一般的な異方性材料の 2 次元 弾性問題における応力関数 $F, \psi$ は以下の連立偏微分方程式を満たす解として与えられる.

$$
\left.\begin{array}{l}
L_{4} F+L_{3} \psi=0 \\
L_{3} F+L_{2} \psi=0
\end{array}\right\}
$$


ここに $L_{j}$ は $j$ 階の偏微分演算子であり, 次式によって与えられる.

$$
\left.\begin{array}{l}
L_{2}=a_{55} \frac{\partial^{2}}{\partial y^{2}}-2 a_{45} \frac{\partial^{2}}{\partial x \partial y}+a_{44} \frac{\partial^{2}}{\partial x^{2}}, \\
L_{3}=a_{15} \frac{\partial^{3}}{\partial y^{3}}-\left(a_{14}+a_{56}\right) \frac{\partial^{3}}{\partial x \partial y^{2}}+\left(a_{25}+a_{46}\right) \frac{\partial^{3}}{\partial x^{2} \partial y}-a_{24} \frac{\partial^{3}}{\partial x^{3}}, \\
L_{4}=a_{11} \frac{\partial^{4}}{\partial y^{4}}-2 a_{16} \frac{\partial^{4}}{\partial x \partial y^{3}}+\left(2 a_{12}+a_{66}\right) \frac{\partial^{4}}{\partial x^{2} \partial y^{2}}-2 a_{26} \frac{\partial^{4}}{\partial x^{3} \partial y}+a_{22} \frac{\partial^{4}}{\partial x^{4}} .
\end{array}\right\}
$$

$L_{3}$ が面内問題と面外せん断問題の連成項に相当する（式（3）参照. 面内（面外せん断）応力によって面外せ ん断（面内）ひずみ成分が発生し， $L_{3}$ はこの連成現象を表す弾性コンプライアンスを含む).

異方性弾性材料の特別な場合として, 面内問題と面外せん断問題の連成を伴わない場合（式（5）の直交異方性 弾性材料を含む）の支配方程式は， $L_{3}=0 （ a_{14}=a_{15}=a_{24}=a_{25}=a_{46}=a_{56}=0 ）$ より，以下のように表せる.

$$
\left.\begin{array}{l}
L_{4} F=0 \\
L_{2} \psi=0
\end{array}\right\}
$$

また，等方性弾性材料の場合，式（5）の弾性コンプライアンスは以下のようになる.

$$
\begin{aligned}
& a_{11}=a_{22}=a_{33}=1 / E, \\
& a_{12}=a_{13}=a_{23}=-v / E, \\
& a_{44}=a_{55}=a_{66}=1 / G=2(1+v) / E, \\
& \text { other } a_{j k}=0 .
\end{aligned}
$$

したがって，面内問題では重調和型，面外せん断問題では調和型の支配方程式に帰着する.

$$
\left.\begin{array}{l}
\nabla^{2} \nabla^{2} F=0, \\
\nabla^{2} \psi=0 .
\end{array}\right\}
$$

ここに， $\nabla^{2}$ はラプラシアンである.

$$
\nabla^{2}=\frac{\partial^{2}}{\partial x^{2}}+\frac{\partial^{2}}{\partial y^{2}}
$$

一般的な異方性弾性材料に対する支配方程式は, 式 (8) に対して式 (9) の偏微分演算子を作用させることで, 6 階の偏微分方程式として与えられる.

$$
\left.\begin{array}{l}
\left(L_{4} L_{2}-L_{3}^{2}\right) F=0, \\
\left(L_{4} L_{2}-L_{3}^{2}\right) \psi=0 .
\end{array}\right\}
$$

以下，式（14）の一般解について記述する，F, $\psi$ が決定されれば，式（6）より応力，式（3）よりひずみ，さ らに式（2）より変位を決定することができる．これらを求める具体的な式は後で述べる.

なお，式（10）で表される異方性弾性材料の特別な場合，あるいは，式（12）の等方性弾性材料の場合の解は, 式（3）に含まれる弾性コンプライアンスを限りなくこれらの条件に近づけることによって求めることができる.

\section{$2 \cdot 4$ 支配方程式の一般解と複素応力関数}

式（14）の一般解は，最終的には複素応力関数 $\phi_{k}\left(z_{k}\right) \quad(k=1,2,3)$ を用いて以下のように表すことができる.

$$
\left.\begin{array}{l}
F(x, y)=2 \operatorname{Re} \sum_{k=1}^{3} \int \phi_{k}\left(z_{k}\right) d z_{k}, \\
\psi(x, y)=2 \operatorname{Re} \sum_{k=1}^{3} \lambda_{k} \phi_{k}\left(z_{k}\right) .
\end{array}\right\}
$$


ここに， $z_{k}=x+\mu_{k} y$ は複素変数である， $\mu_{k}$ は，材料異方性の程度を表す複素定数であり，式（16）に示す複素変 数 $\mu$ の 6 次特性方程式の根として求められる（Lekhnitskii, 1964）.

$$
l_{4}(\mu) l_{2}(\mu)-l_{3}^{2}(\mu)=0 .
$$

ここに,

$$
\left.\begin{array}{l}
l_{2}(\mu)=a_{55} \mu^{2}-2 a_{45} \mu+a_{44}, \\
l_{3}(\mu)=a_{15} \mu^{3}-\left(a_{14}+a_{56}\right) \mu^{2}+\left(a_{25}+a_{46}\right) \mu-a_{24}, \\
l_{4}(\mu)=a_{11} \mu^{4}-2 a_{16} \mu^{3}+\left(2 a_{12}+a_{66}\right) \mu^{2}-2 a_{26} \mu+a_{22} .
\end{array}\right\}
$$

なお式（16）の根は 3 組の共役複素数になることが証明されており，虚数部が正の 3 根を $\mu_{k}$ として用いる.

また，式（15）に含まれる $\lambda_{k}$ は面内問題と面外せん断問題の連成の程度を示す複素定数であり，式（18）によ って決定される.

$$
\lambda_{k}=-\frac{l_{3}\left(\mu_{k}\right)}{l_{2}\left(\mu_{k}\right)}=-\frac{l_{4}\left(\mu_{k}\right)}{l_{3}\left(\mu_{k}\right)} .
$$

複素応力関数 $\phi_{k}\left(z_{k}\right)$ は，対象とする 2 次元弾性問題の境界条件を考慮して決定されるものである.

\section{$2 \cdot 5$ 写像関数}

前節において述べたように，異方性弾性問題ではアフィン変換された複素変数 $z_{k}=x+\mu_{k} y$ を用いて，解析解を 求めることが一般的である.

一例として, 図 2 に示すようにだ円筒の外側境界 $L_{1}$, 内側境界 $L_{2}$ が, ともに焦点を同じくする場合 $\left(b_{1} / a_{1}=\right.$

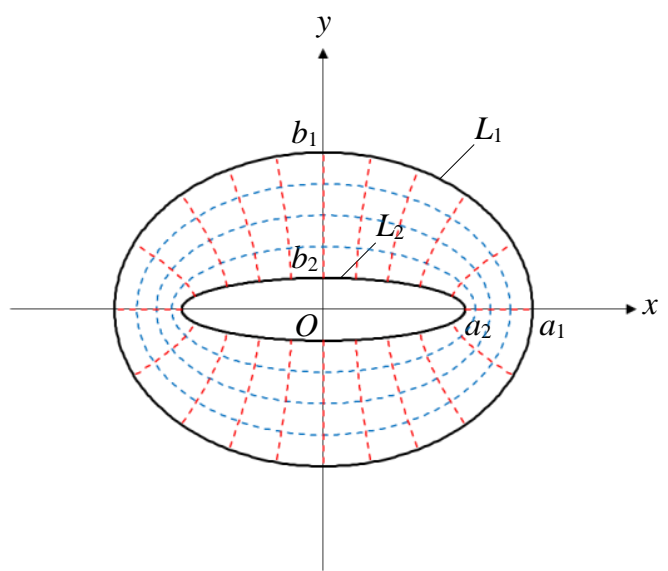

Fig. 2 Complex plane $z=x+i y$.

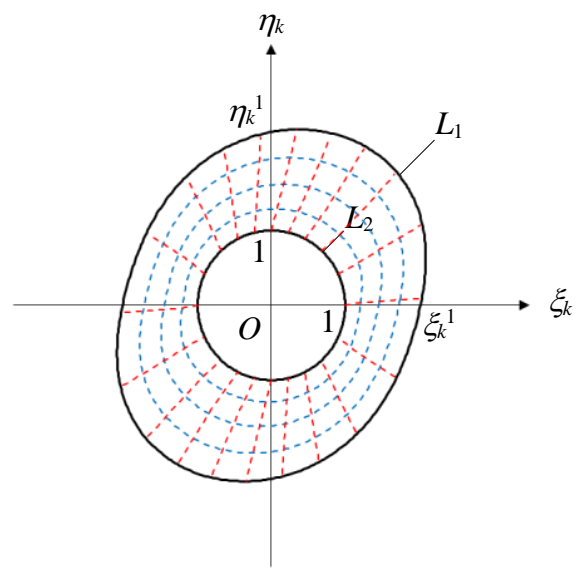

(a) Case of anisotropic material.

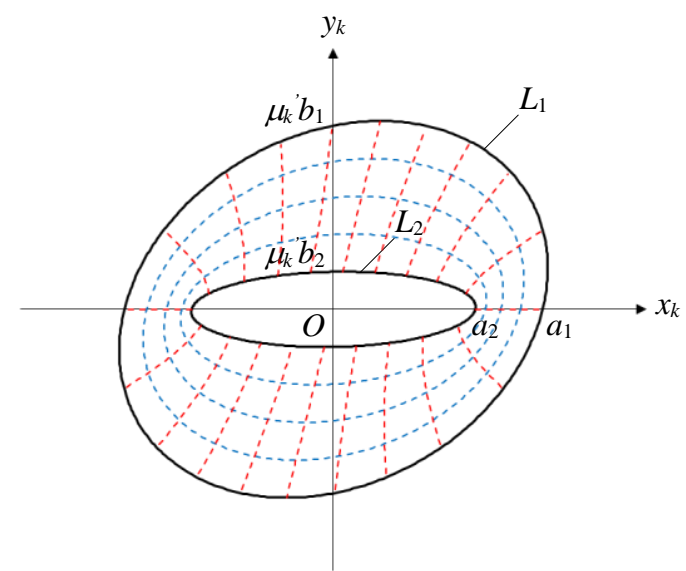

Fig. 3 Affine transformation $z_{k}=x+\mu_{k} y$.

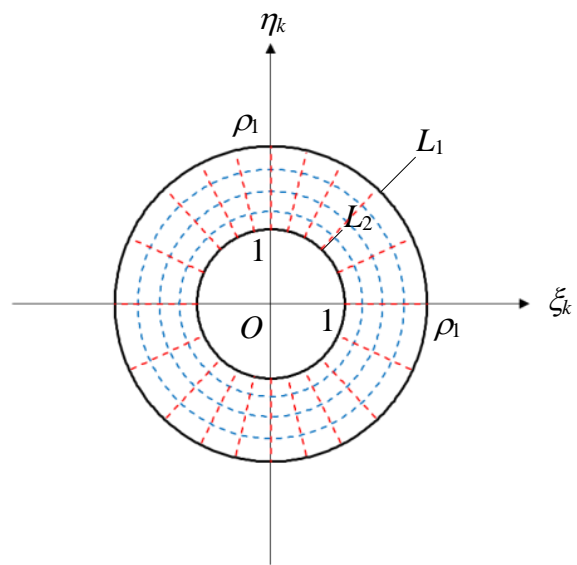

(b) Case of isotropic material.

Fig. 4 Mapping result due to Eq. (19). 
$\left.0.75, b_{2} / b_{1}=0.20\right)$ で, 式（16）の 1 根が $\mu_{k}=0.3+1.2 i$ で表されるような異方性弾性材料について, アフィン変換 後のだ円筒断面を図 3 の $z_{k}$ 平面 $\left(z_{k}=x_{k}+i y_{k}\right)$ に示す. ここに, $\mu_{k}=\mu_{k}^{\prime}+i \mu_{k}^{\prime} \quad\left(\mu_{k}^{\prime}, \mu_{k}^{\prime}\right.$ はともに実数で, $\left.\mu_{k}^{\prime}>0\right)$ と置いて, $x_{k}=x+\mu_{k} y, y_{k}=\mu_{k} y$ としている. 等方性弾性材料では, 特性根 $\mu_{k}=i$ となるために, 図 3 に相当する $z_{k}$ 平面（アフィン変換面）は図 2 の $z$ 平面と同じものになることが分かる.

2 次元弾性理論では，後述するように解析を容易にする目的から， $z$ 平面上の任意形状の境界 $L$ を, 一旦図 3 に示す $z_{k}$ 平面上にアフィン変換し，この境界をさらに $\zeta_{k}$ 平面上の単位円に写像することが行われる. 図 2 のよう に, 一般に $z$ 平面上で長軸 $a$, 短軸 $b$ のだ円境界 $L$ を有する場合，これを $\zeta_{k}$ 平面上の単位円に変換する写像関数 は，次式によって与えられる（丹羽他，1970a）.

$$
z_{k}=\omega_{k}\left(\zeta_{k}\right)=R_{k}\left(\zeta_{k}+\frac{m_{k}}{\zeta_{k}}\right) .
$$

ここに,

$$
\left.\begin{array}{l}
R_{k}=\frac{a-i \mu_{k} b}{2}, \\
m_{k}=\frac{a+i \mu_{k} b}{a-i \mu_{k} b} .
\end{array}\right\}
$$

図 4 は, 図 2 に示寸だ円筒断面の内側境界 $L_{2}$ が， $\zeta_{k}$ 平面上で単位円となるように，式（19）によって変換した 結果を示している.このうち, 図 4 (a) が異方性弾性材料（図 3 の $z_{k}$ 平面）に対する変換結果，図 4 (b) が等 方性弹性材料（(図 2 の $z$ 平面）に対する変換結果を示している.

内側境界 $L_{2}$ はともに単位円に写像されており，正しく変換されていることが分かる．続いて，外側境界 $L_{1} に$ ついて，ここでの例のように，2 境界が共焦だ円群で構成される場合を見てみる.

まず図 4 (b) に示寸等方性弾性材料では， $L_{1}$ は $\zeta_{k}$ 平面上で内側境界 $L_{2}$ の単位円と原点を共有する同心円とな る. $L_{1}$ の円の半径を $\rho_{1}$ とすると, これは次式によって与えられる.

$$
\rho_{1}=\frac{a_{1}+b_{1}}{a_{2}+b_{2}}
$$

図 2 の $x, y$ 軸は図 4 (b) の $\xi, \eta_{k}$ 軸に変換され，原点まわりの回転なく，両軸の直交性が保障される.

次に異方性弾性材料の場合, 図 4 (a) に示されるように $L_{1}$ と $L_{2}$ は同心円領域に写像されない. 同図の $\xi_{k}, \eta_{k}$ 軸 と $L_{1}$ 境界との交点を $\xi_{k}^{1}, \eta_{k}^{1}$ とすると, これらは次式によって求めることができる.

$$
\begin{aligned}
& \frac{1}{\xi_{k}^{1}}=\frac{1}{a_{2}}\left[\left\{-\frac{\mu_{k}-\bar{\mu}_{k}}{\mu_{k}+\bar{\mu}_{k}}\left(\frac{\mu_{k}-\bar{\mu}_{k}}{2}+i \frac{a_{2}}{b_{2}}\right)+\frac{\mu_{k}+\bar{\mu}_{k}}{2}\right\} b_{1} \sin \theta_{1}+a_{1} \cos \theta_{1}\right], \\
& \frac{1}{\eta_{k}^{1}}=\frac{1}{b_{2}}\left\{b_{1} \sin \theta_{2}+\frac{\mu_{k}-\bar{\mu}_{k}}{\mu_{k}+\bar{\mu}_{k}}\left(\frac{2}{\mu_{k}-\bar{\mu}_{k}}-i \frac{b_{2}}{a_{2}}\right) a_{1} \cos \theta_{2}\right\} .
\end{aligned}
$$

ここに，上付バーは共役複素数を表す．また，角度 $\theta_{j}(j=1,2)$ はそれぞれ式(22)を以下の式に代入して得られる 超越方程式の解である.

$$
\left.\begin{array}{l}
b_{1} \sin \theta_{1}+\frac{i}{2} \frac{\mu_{k}+\bar{\mu}_{k}}{\mu_{k}-\bar{\mu}_{k}} b_{2}\left(\xi_{k}^{1}+\frac{1}{\xi_{k}^{1}}\right)=0, \\
a_{1} \cos \theta_{2}+\frac{\mu_{k}+\bar{\mu}_{k}}{2} b_{1} \sin \theta_{2}-\frac{\mu_{k}+\bar{\mu}_{k}}{4} b_{2}\left(\eta_{k}^{1}+\frac{1}{\eta_{k}^{1}}\right)=0 .
\end{array}\right\}
$$

等方性弾性材料では, 複素フーリエ級数の導入により解析を容易に行えるため, だ円筒の 2 境界が焦点を同じ くする場合について, 解が求められてきた. しかしながら, 2 境界の焦点が異なる場合, この方法は利用できず, 適用範囲が限定的である. 異方性弾性材料の場合はもはや解析的に解くことは困難である.

そこで, 本研究では拘束解除法と呼ばれる収束計算手法を導入し, 2 モデルの解析解に基づいて精度よく近似 解を求める方法を示寸.この方法によれば，だ円筒の 2 境界が焦点を異にする問題はもとより, 複数モデルの解 析解を用いることにより, 様々な問題へと拡張して解を求めることができるというメリットがある. 


\section{$2 \cdot 6$ 合力, 応力および変位の一般式}

式（15）により, 異方性弾性問題の 2 次元問題については, 境界条件を考慮して複素応力関数 $\phi_{k}\left(z_{k}\right)$ を決定寸れ ば, 合力, 応力および変位の各成分を次式によって求めることができる.なお, 式 (19) の写像関数を考慮して, 以下複素応力関数を $\phi_{k}\left(\zeta_{k}\right)$ と表す.

応力成分は，式（15）を式（6）に代入することにより，次式で求めることができる.

$$
\begin{aligned}
& \sigma_{x}=2 \operatorname{Re} \sum_{k=1}^{3} \mu_{k}^{2} \phi_{k}^{\mathrm{I}}\left(\zeta_{k}\right), \\
& \sigma_{y}=2 \operatorname{Re} \sum_{k=1}^{3} \phi_{k}^{\mathrm{I}}\left(\zeta_{k}\right), \\
& \tau_{y z}=-2 \operatorname{Re} \sum_{k=1}^{3} \lambda_{k} \phi_{k}^{\mathrm{I}}\left(\zeta_{k}\right), \\
& \tau_{x z}=2 \operatorname{Re} \sum_{k=1}^{3} \mu_{k} \lambda_{k} \phi_{k}^{\mathrm{I}}\left(\zeta_{k}\right), \\
& \tau_{x y}=-2 \operatorname{Re} \sum_{k=1}^{3} \mu_{k} \phi_{k}^{\mathrm{I}}\left(\zeta_{k}\right) .
\end{aligned}
$$

ここに上付文字 $\mathrm{I}$ は, 複素変数 $z_{k}$ による微分を表す. 複素変数 $\zeta_{k}$ による微分をプライム記号で表すことにすると, 複素応力関数の一回微分は以下のように求まる.

$$
\phi_{k}^{\mathrm{I}}\left(\zeta_{k}\right)=\frac{\partial \phi_{k}\left(\zeta_{k}\right)}{\partial z_{k}}=\frac{\phi_{k}^{\prime}\left(\zeta_{k}\right)}{\omega_{k}^{\prime}\left(\zeta_{k}\right)} .
$$

本論文のように，だ円境界を単位円に写像する場合には，式（19）より上式は次のように書ける.

$$
\phi_{k}^{\mathrm{I}}\left(\zeta_{k}\right)=\frac{\zeta_{k}^{2}}{R_{k}\left(\zeta_{k}^{2}-m_{k}\right)} \phi_{k}^{\prime}\left(\zeta_{k}\right)
$$

合力成分は，式（24）の応力成分を積分することによって求めることができる.

$$
\begin{aligned}
& \pm P_{x}=-2 \operatorname{Re} \sum_{k=1}^{3} \mu_{k} \phi_{k}\left(\zeta_{k}\right), \\
& \pm P_{y}=2 \operatorname{Re} \sum_{k=1}^{3} \phi_{k}\left(\zeta_{k}\right), \\
& \pm P_{z}=2 \operatorname{Re} \sum_{k=1}^{3} \lambda_{k} \phi_{k}\left(\zeta_{k}\right)
\end{aligned}
$$

ここに左辺の複号は境界の内外を区別するもので，内側境界の場合に正号，外側境界の場合に負号をとる.

変位成分は，式（3）の構成方程式に式（24）を代入してひずみ成分を求め，式（2）の幾何式を考慮してこれ らひずみ成分を積分することによって求めることができる.

$$
\begin{aligned}
& u=2 \operatorname{Re} \sum_{k=1}^{3} \mu_{k} p_{k} \phi_{k}\left(\zeta_{k}\right), \\
& v=2 \operatorname{Re} \sum_{k=1}^{3} q_{k} \phi_{k}\left(\zeta_{k}\right), \\
& w=2 \operatorname{Re} \sum_{k=1}^{3} r_{k} \phi_{k}\left(\zeta_{k}\right) .
\end{aligned}
$$

ここに, $p_{k}, q_{k}$ および $r_{k}$ は以下の複素定数である.

$$
\begin{aligned}
& \mu_{k} p_{k}=a_{11} \mu_{k}^{2}+a_{12}-a_{16} \mu_{k}+\lambda_{k}\left(a_{15} \mu_{k}-a_{14}\right), \\
& \mu_{k} q_{k}=a_{12} \mu_{k}^{2}+a_{22}-a_{26} \mu_{k}+\lambda_{k}\left(a_{25} \mu_{k}-a_{24}\right), \\
& \mu_{k} r_{k}=a_{14} \mu_{k}^{2}+a_{24}-a_{46} \mu_{k}+\lambda_{k}\left(a_{45} \mu_{k}-a_{44}\right) .
\end{aligned}
$$




\section{3. 拘束解除法と解の導出}

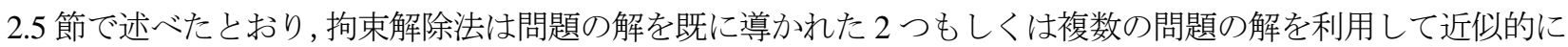
求める方法である. 本研究では図 1 のだ円筒の解を求めるために, 既に導かれている問題の解として, 図 5 拉よ び図 6 に示されただ円柱およびだ円孔を有する無限体の解を用いる，以下，各々の解析モデルについて触れ，こ れらの解を利用した拘束解除法について説明する。

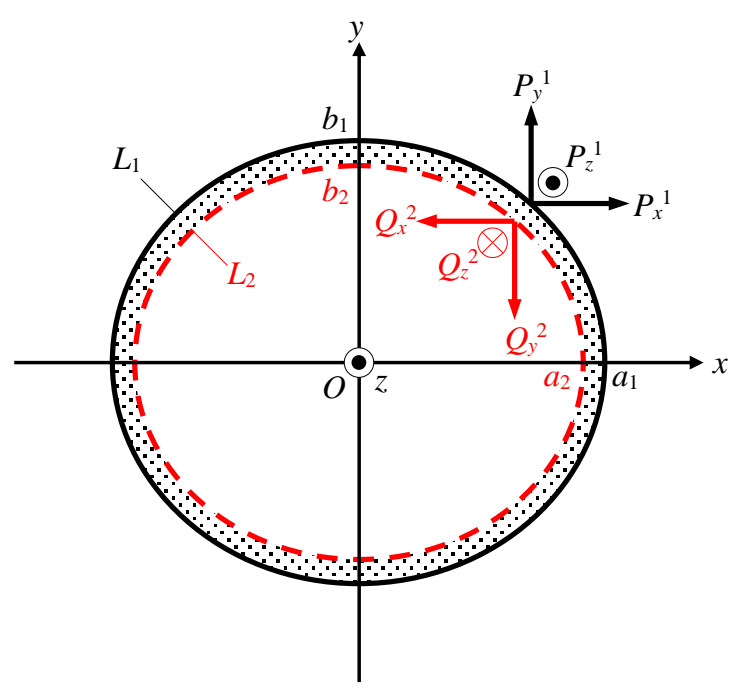

Fig. 5 Elliptic cylinder subjected to arbitrary loadings $X_{1}, Y_{1}$ and $Z_{1}$ on its lateral surface $L_{1}$.

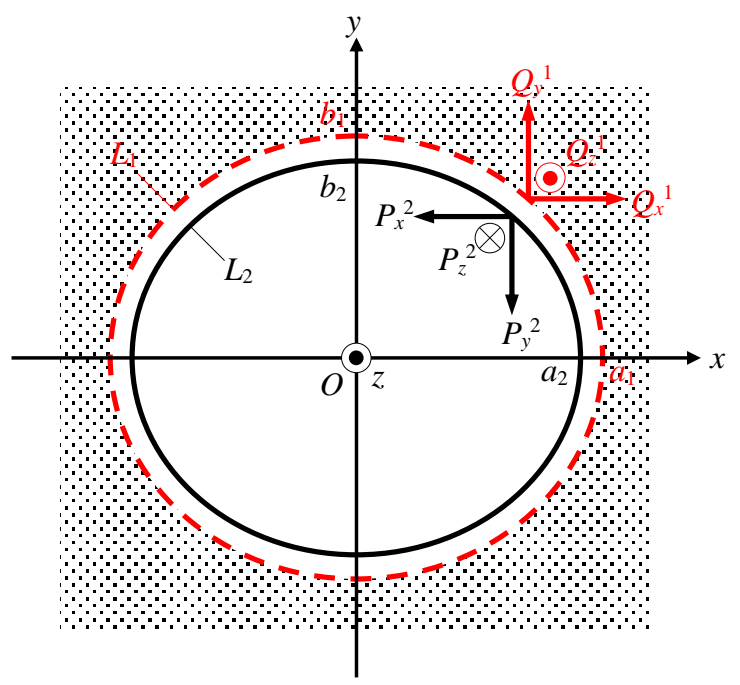

Fig. 6 Infinite body with an elliptic cavity subjected to arbitrary loadings $X_{2}, Y_{2}$ and $Z_{2}$ on its inner boundary $L_{2}$.

\section{$3 \cdot 1$ だ円柱の側面に外カが作用する問題}

図 5 は，図 1 のだ円筒の外側境界 $L_{1}$ を側面にもつだ円柱を示している。この境界に任意の外力 $P_{x}{ }^{1}, P_{y}{ }^{1}$ および $P_{z}{ }^{1}$ が作用している問題の複素応力関数を $\phi_{k 1}\left(\zeta_{k 1}\right)$ と表すと, これは次式によって与えられる (Lekhnitskii, 1958).

$$
\phi_{k 1}\left(\zeta_{k 1}\right)=\Gamma_{k 0,1}+R_{k 1} \Gamma_{k 1,1}\left(\zeta_{k 1}+\frac{m_{k 1}}{\zeta_{k 1}}\right)-\sum_{n=2}^{\infty} \Gamma_{k n, 1}\left\{\zeta_{k 1}^{n}+\left(\frac{m_{k 1}}{\zeta_{k 1}}\right)^{n}\right\} .
$$

ここに， $\zeta_{k 1}$ は式（19）により $L_{1}$ 境界を単位円に写寸写像変数である. $R_{k 1}, m_{k 1}$ は式（20）において $a=a_{1}, b=b_{1}$ とした複素定数であり, 右辺の第 1 項は一様な合力, 変位場を, 第 2 項は一様な応力場を規定するものである.

また, $\Gamma_{k n, 1}$ は $L_{1}$ 境界の負荷条件から定めることのできる複素定数であるが現時点では未知の量である. そこで, $L_{1}$ 境界上の外力を周期 $2 \pi$ の複素フーリエ級数として以下のように表示することにする. 


$$
\begin{aligned}
& -P_{x}^{1}=-\alpha_{0,1}-\sum_{n=1}^{\infty}\left(\bar{\alpha}_{n, 1} \mathrm{e}^{-i n \theta}+\alpha_{n, 1} \mathrm{e}^{i n \theta}\right), \\
& -P_{y}^{1}=\beta_{0,1}+\sum_{n=1}^{\infty}\left(\bar{\beta}_{n, 1} \mathrm{e}^{-i n \theta}+\beta_{n, 1} \mathrm{e}^{i n \theta}\right) \\
& -P_{z}^{1}=\gamma_{0,1}+\sum_{n=1}^{\infty}\left(\bar{\gamma}_{n, 1} \mathrm{e}^{-i n \theta}+\gamma_{n, 1} \mathrm{e}^{i n \theta}\right)
\end{aligned}
$$

ここに， $\alpha_{n, 1}, \beta_{n, 1}$ および $\gamma_{n, 1}$ は複素フーリエ係数（既知量）であり，バ一記号は共役複素数を表す。また， e はネイ ピアの数, $i$ は虚数単位, $\theta$ は $x$ 軸正の方向から反時計回りに測った角度を表す.

式（24）, 式（27）および式（28）を用いて $L_{1}$ 境界上の応力, 合力あるいは変位を求め（式（19）より $L_{1}$ 境界

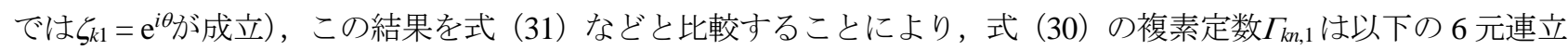
1 次方程式を解くことにより決定される. なお， $n=0$ のときの剛体変位は全て 0 と置いた.

$$
\left.\begin{array}{l}
\sum_{k=1}^{3}\left(\mu_{k} \Gamma_{k 0,1}+\bar{\mu}_{k} \bar{\Gamma}_{k 0,1}\right)=\alpha_{0,1}, \quad \sum_{k=1}^{3}\left(\Gamma_{k 0,1}+\bar{\Gamma}_{k 0,1}\right)=\beta_{0,1}, \\
\left.\sum_{k=1}^{3}\left(\lambda_{k} \Gamma_{k 0,1}+\bar{\lambda}_{k} \bar{\Gamma}_{k 0,1}\right)=\gamma_{0,1}, \sum_{k=1}^{3}\left(\mu_{k} p_{k} \Gamma_{k 0,1}+\bar{\mu}_{k} \bar{p}_{k} \bar{\Gamma}_{k 0,1}\right)=0, \quad\right\} \text { for } n=0 . \\
\sum_{k=1}^{3}\left(q_{k} \Gamma_{k 0,1}+\bar{q}_{k} \bar{\Gamma}_{k 0,1}\right)=0, \sum_{k=1}^{3}\left(r_{k} \Gamma_{k 0,1}+\bar{r}_{k} \bar{\Gamma}_{k 0,1}\right)=0, \\
\sum_{k=1}^{3}\left(\mu_{k}^{2} \Gamma_{k 1,1}+\bar{\mu}_{k}^{2} \bar{\Gamma}_{k 1,1}\right)=\frac{\alpha_{1,1}-\bar{\alpha}_{1,1}}{i b_{1}}, \sum_{k=1}^{3}\left(\Gamma_{k 1,1}+\bar{\Gamma}_{k 1,1}\right)=-\frac{\beta_{1,1}+\bar{\beta}_{1,1}}{a_{1}}, \\
\sum_{k=1}^{3}\left(\lambda_{k} \Gamma_{k 1,1}+\bar{\lambda}_{k} \bar{\Gamma}_{k 1,1}\right)=\frac{\gamma_{1,1}+\bar{\gamma}_{1,1}}{a_{1}, \sum_{k=1}^{3}\left(\mu_{k} \lambda_{k} \Gamma_{k 1,1}+\bar{\mu}_{k} \bar{\lambda}_{k} \bar{\Gamma}_{k 1,1}\right)=-\frac{\gamma_{1,1}-\bar{\gamma}_{1,1}}{i b_{1}},} \\
\sum_{k=1}^{3}\left(\mu_{k} \Gamma_{k 1,1}+\bar{\mu}_{k} \bar{\Gamma}_{k 1,1}\right)=\frac{\beta_{1,1}-\bar{\beta}_{1,1}}{i b_{1}}=-\frac{\alpha_{1,1}+\bar{\alpha}_{1,1}}{a_{1}}, \sum_{k=1}^{3}\left\{\left(q_{k}-\mu_{k}^{2} p_{k}\right) \Gamma_{k 1,1}+\left(\bar{q}_{k}-\bar{\mu}_{k}^{2} \bar{p}_{k}\right) \bar{\Gamma}_{k 1,1}\right\}=0, \\
\sum_{k=1}^{3}\left(\mu_{k} m_{k}^{n} \Gamma_{k n, 1}+\bar{\mu}_{k} \bar{\Gamma}_{k n, 1}\right)=-\bar{\alpha}_{n, 1}, \sum_{k=1}^{3}\left(\mu_{k} \Gamma_{k n, 1}+\bar{\mu}_{k} \bar{m}_{k}^{n} \bar{\Gamma}_{k n, 1}\right)=-\alpha_{n, 1}, \\
\sum_{k=1}^{3}\left(m_{k}^{n} \Gamma_{k n, 1}+\bar{\Gamma}_{k n, 1}\right)=-\bar{\beta}_{n, 1}, \sum_{k=1}^{3}\left(\Gamma_{k n, 1}+\bar{m}_{k}^{n} \bar{\Gamma}_{k n, 1}\right)=-\beta_{n, 1}, \\
\sum_{k=1}^{3}\left(\lambda_{k} m_{k}^{n} \Gamma_{k n, 1}+\bar{\lambda}_{k} \bar{\Gamma}_{k n, 1}\right)=-\bar{\gamma}_{n, 1}, \sum_{k=1}^{3}\left(\lambda_{k} \Gamma_{k n, 1}+\bar{\lambda}_{k} \bar{m}_{k}^{n} \bar{\Gamma}_{k n, 1}\right)=-\gamma_{n, 1},
\end{array}\right\} \text { for } n=1 .
$$

以上より, 図 5 の応力, 合力および変位を求めることができる.

\section{$3 \cdot 2$ 無限体内部のだ円孔に外カが作用する問題}

図 6 は，図 1 のだ円筒の内側境界 $L_{2}$ を空孔にもつ無限弾性体を示している。この空孔に任意の外力 $P_{x}^{2}, P_{y}^{2}$ お よび $P_{z}^{2}$ が作用する問題の複素応力関数を $\phi_{k 2}\left(\zeta_{k 2}\right)$ と表すと, これは次式で与えられる (Lekhnitskii, 1964).

$$
\phi_{k 2}\left(\zeta_{k 2}\right)=\sum_{n=0}^{\infty} \Gamma_{k n, 2} \frac{1}{\zeta_{k 2}^{n}}
$$

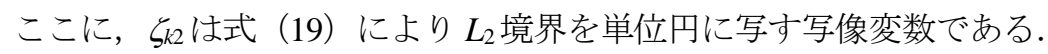

また， $\Gamma_{k n, 2}$ は $L_{2}$ 境界の負荷条件から定めることのできる複素定数であるが，現時点では未知の量である，そこ で， $L_{2}$ 境界上の外力を周期 $2 \pi$ の複素フーリエ級数として以下のように表示することにする.

$$
\begin{aligned}
& P_{x}^{2}=-\alpha_{0,2}-\sum_{n=1}^{\infty}\left(\bar{\alpha}_{n, 2} \mathrm{e}^{-i n \theta}+\alpha_{n, 2} \mathrm{e}^{i n \theta}\right), \\
& P_{y}^{2}=\beta_{0,2}+\sum_{n=1}^{\infty}\left(\bar{\beta}_{n, 2} \mathrm{e}^{-i n \theta}+\beta_{n, 2} \mathrm{e}^{i n \theta}\right), \\
& P_{z}^{2}=\gamma_{0,2}+\sum_{n=1}^{\infty}\left(\bar{\gamma}_{n, 2} \mathrm{e}^{-i n \theta}+\gamma_{n, 2} \mathrm{e}^{i n \theta}\right) .
\end{aligned}
$$


ここに， $\alpha_{n, 2}, \beta_{n, 2}$ および $\gamma_{n, 2}$ は複素フーリエ係数（既知量）であり，バー記号は共役複素数を表す．

式（27）および式（28）を用いて $L_{2}$ 境界上の合力あるいは変位を計算し（式（19）より $L_{2}$ 境界では $\zeta_{k 2}=\mathrm{e}^{i \theta か ゙ ~}$ 成立), この結果を式（36）等と比較することにより, 式（35）の複素定数 $\Gamma_{k n, 2}$ は以下の 6 元あるいは 3 元連立 1 次方程式を解いて決定される.

$$
\begin{aligned}
& n=0 \\
& \left.\begin{array}{l}
\sum_{k=1}^{3}\left(\mu_{k} \Gamma_{k 0,2}+\bar{\mu}_{k} \bar{\Gamma}_{k 0,2}\right)=\alpha_{0,2}, \quad \sum_{k=1}^{3}\left(\Gamma_{k 0,2}+\bar{\Gamma}_{k 0,2}\right)=\beta_{0,2}, \\
\sum_{k=1}^{3}\left(\lambda_{k} \Gamma_{k 0,2}+\bar{\lambda}_{k} \bar{\Gamma}_{k 0,2}\right)=\gamma_{0,2}, \sum_{k=1}^{3}\left(\mu_{k} p_{k} \Gamma_{k 0,2}+\bar{\mu}_{k} \bar{p}_{k} \bar{\Gamma}_{k 0,2}\right)=0, \\
\sum_{k=1}^{3}\left(q_{k} \Gamma_{k 0,2}+\bar{q}_{k} \bar{\Gamma}_{k 0,2}\right)=0, \quad \sum_{k=1}^{3}\left(r_{k} \Gamma_{k 0,2}+\bar{r}_{k} \bar{\Gamma}_{k 0,2}\right)=0,
\end{array}\right\} \text { for } n=0 . \\
& \sum_{k=1}^{3} \mu_{k} \Gamma_{k n, 2}=\bar{\alpha}_{n, 2}, \\
& \left.\begin{array}{l}
\sum_{k=1}^{3} \Gamma_{k n, 2}=\bar{\beta}_{n, 2}, \\
\sum_{k=1}^{3} \lambda_{k} \Gamma_{k n, 2}=\bar{\gamma}_{n, 2},
\end{array}\right\} \text { for } n \geq 1 .
\end{aligned}
$$

以上より, 図 6 の応力, 合力および変位を求めることができる.

\section{$3 \cdot 3$ 拘束解除法について}

図 5 および図 6 には，赤色の破線で仮想境界（それぞれ， $L_{2}$ および $L_{1}$ ）が示してある. 拘束解除法では，これ らの仮想境界 $L_{j}(j=1,2)$ の合力を式 (27) で求めることが必要になってくる（図中には, 記号 $Q_{x}^{j}, Q_{y}^{j}$ および $Q_{z}^{j}$ により，これら仮想境界上の合力が表されている). 拘束解除法の手順を以下に示す.

(1) だ円柱（図 5）の $L_{1}$ 境界に, だ円筒（図 1） $L_{1}$ 境界の外力 $P_{x}{ }^{1}=X_{1}, P_{y}{ }^{1}=Y_{1}, P_{z}{ }^{1}=Z_{1}$ を作用させ, 仮想境界 $L_{2}$ の合力 $Q_{x}^{2}, Q_{y}^{2}, Q_{z}^{2}$ を求める.

(2) 無限体（図 6）の $L_{2}$ 境界に，だ円筒（図 1） $L_{2}$ 境界の外力および前記11の反符号力を合計したもの，すな わち, $P_{x}^{2}=X_{2}-Q_{x}{ }^{2}, P_{y}{ }^{2}=Y_{2}-Q_{y}{ }^{2}, P_{z}{ }^{2}=Z_{2}-Q_{z}{ }^{2}$ を作用させ, 仮想境界 $L_{1}$ の合力 $Q_{x}{ }^{1}, Q_{y}{ }^{1}, Q_{z}{ }^{1}$ を求める.

(3) だ円柱（図 5)の $L_{1}$ 境界に, 前記(2)の反符号力, 寸なわち, $P_{x}{ }^{1}=-Q_{x}{ }^{1}, P_{y}{ }^{1}=-Q_{y}{ }^{1}, P_{z}{ }^{1}=-Q_{z}{ }^{1}$ を作用させ, 仮想境界 $L_{2}$ の合力 $Q_{x}^{2}, Q_{y}^{2}, Q_{z}^{2}$ を求める.

(4) 無限体 (図 6) の $L_{2}$ 境界に, 前記(3)の反符号力, 寸なわち, $P_{x}^{2}=-Q_{x}{ }^{2}, P_{y}{ }^{2}=-Q_{y}{ }^{2}, P_{z}{ }^{2}=-Q_{z}{ }^{2}$ を作用させ, 仮想境界 $L_{1}$ の合力 $Q_{x}{ }^{1}, Q_{y}{ }^{1}, Q_{z}{ }^{1}$ を求める.

(5) 前記(3)，(4)の操作を，仮想境界上の合力が十分小さくなるまで繰り返す.

前記(1)〜(5)には, 図 5 のだ円柱では式（32）から式（34）により，図6の無限体では式（37）から式（38）に より，複素応力関数に含まれる未定係数を決定するプロセスが含まれる.

いま, 繰返し数 $m$ のときの未定係数を $\Gamma_{k n, j}{ }^{m}$ と表すことにする. これら 2 モデル間で行う収束計算回数を $M_{C}$ と すると，最終的に式（30）および式（35）の未定係数 $\Gamma_{k n, j}$ は次式によって求められる.

$$
\Gamma_{k n, j}=\sum_{m=1}^{M_{C}} \Gamma_{k n, j}^{m} .
$$

したがって，式（39）を式（30）もしくは式（35）の 2 モデルの複素応力関数に代入し，これら 2 モデルのだ 円筒領域の応力, 合力, 変位を式 (24), 式 (27) および式 (28) により計算, これらを合計することにより, 対 象としている図 1 のだ円筒の解を得ることができる.

\section{4. 数值計算例}

だ円筒は，互いに直交する弾性主軸を有する異方性材料からなると仮定し，3方向の縦弾性係数 $E_{j} \quad(j=1,2,3)$ の関係を以下のように置き，応力や変位分布の計算を行う. 


$$
\frac{E_{2}}{E_{1}}=0.200, \frac{E_{3}}{E_{1}}=1.000
$$

3 つの弾性主軸で形成される $j-k$ 平面内のポアソン比 $v_{j k}$ は以下の值とする.

$$
v_{12}=v_{13}=v_{32}=0.250 \text {. }
$$

$j-k$ 平面内の横弾性係数 $G_{j k}$ については，等方性の場合の式に帰着する以下の仮定式を用いて計算する.

$$
\frac{1}{G_{j k}}=\frac{1}{E_{j}}+\frac{1}{E_{k}}+\frac{2 v_{j k}}{E_{j}}
$$

本研究では，図 1 における代表的な作用荷重として，x-y 平面内において作用する静圧および対向集中荷重の 2 種類を対象に数值計算例を示す.

\section{4:1 作用荷重と複素フーリエ係数}

2 種類の外力について, 式 (33) あるいは式 (38) に含まれる複素フーリエ係数を求めると以下のようになる.

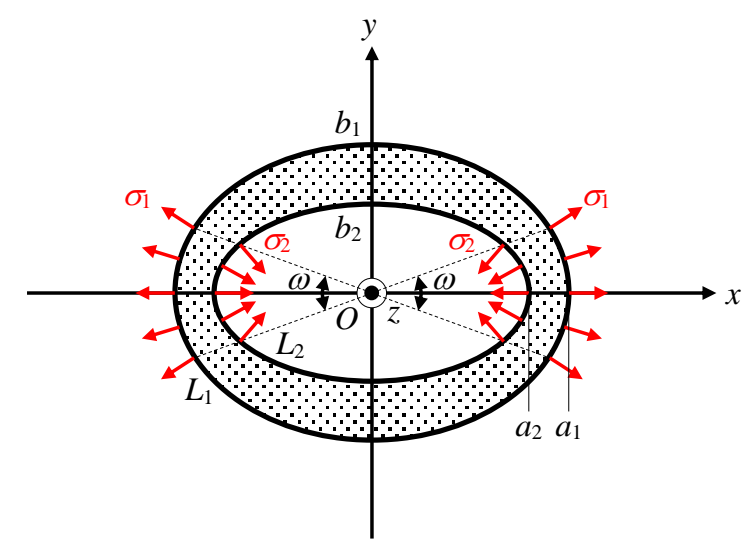

Fig. 7 Hollow cylindroid subjected static pressure $\sigma_{j}$ at both boundaries $L_{j}$.

\section{4・1 1 静圧が作用する場合}

図 7 に示すように, $x$ 軸を挟む領域角 $\omega の$ 範囲の境界 $L_{j}$ に静圧 $\sigma_{j}$ が作用する場合, 複素フーリエ係数は次式によ って与えられる.

$$
\left.\begin{array}{l}
\alpha_{1, j}=-\frac{i b_{j} \sigma_{j}}{2 \pi}\left(2 \theta_{j}+\sin 2 \theta_{j}\right), \\
\alpha_{n, j}=-\frac{i b_{j} \sigma_{j}}{n \pi} \sin ^{2} \frac{n \pi}{2}\left\{\frac{1}{n-1} \sin (n-1) \theta_{j}+\frac{1}{n+1} \sin (n+1) \theta_{j}\right\}, \\
\beta_{1, j}=\frac{a_{j} \sigma_{j}}{2 \pi}\left(2 \theta_{j}-\sin 2 \theta_{j}\right), \\
\beta_{n, j}=\frac{a_{j} \sigma_{j}}{n \pi} \sin ^{2} \frac{n \pi}{2}\left\{\frac{1}{n-1} \sin (n-1) \theta_{j}-\frac{1}{n+1} \sin (n+1) \theta_{j}\right\},
\end{array}\right\}(j=1,2, \quad n \geq 2) .
$$

式（31）および式（36）のその他の複素フーリエ係数は 0 となる. $\theta_{j}$ は $L_{j}$ 境界の偏平率 $f_{j}=b_{j} / a_{j}$ および静圧作用 領域角 $\omega$ より定まる定数である.

$$
\theta_{j}=\tan ^{-1}\left(\frac{1}{f_{j}} \tan \omega\right) .
$$

\section{4・1 - 2 対向集中荷重が作用する場合}

図 8 のように $x$ 軸上 $L_{j}$ 境界に対向して作用する集中荷重の場合, 複素フーリエ係数は次式によって求めること ができる. 


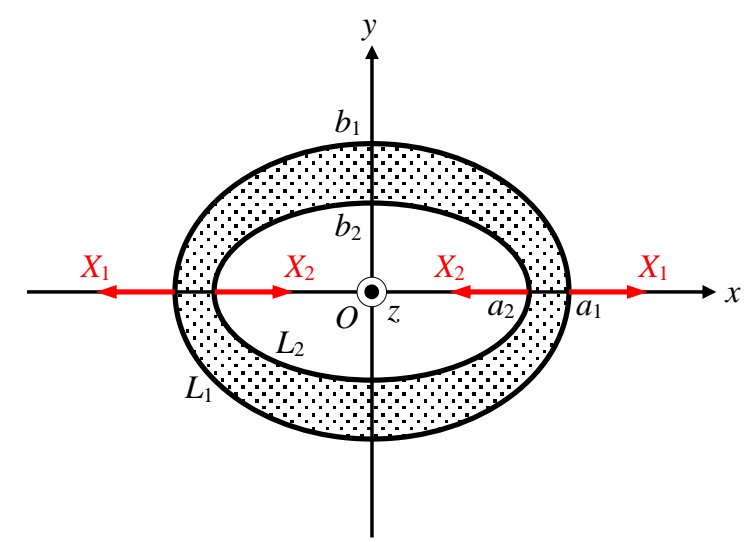

Fig. 8 Hollow cylindroid subjected uniaxial loadings $X_{j}$ at both boundaries $L_{j}$.

$$
\left.\begin{array}{l}
\alpha_{0, j}=-\frac{X_{j}}{2}, \\
\alpha_{n, j}=\frac{i X_{j}}{n \pi} \sin ^{2} \frac{n \pi}{2},
\end{array}\right\} \quad(j=1,2, \quad n \geq 1)
$$

式（31）および式（36）のその他の複素フーリエ係数は 0 となる.

\section{$4 \cdot 2$ 複素応力関数の打切り項数および収束計算回数が計算精度に及ぼす影響}

だ円筒の解の精度は, 式（30）および式（35）のように無限級数で表される複素応力関数の打切り項数 $N_{C}$, 式

（39）の収束計算回数 $M_{C}$ の 2 つの影響を受ける. そこで，対向集中荷重の場合を対象に，これら 2 変数と解の 収束精度の関係について検討した。

図 9 は，図 8 において $X_{1}$ のみが作用し， $X_{2}=0$ である共焦だ円筒 $\left(f_{1}=b_{1} / a_{1}=0.750, t=1-a_{2} / a_{1}=0.250\right)$ に ついて, 各境界の合力 $P_{x}$ とこれら 2 変数との関係を示している.

まず, 図 9 (a) は収束計算回数を十分に大きい $M_{C}=100$ にとり, 複素応力関数の打切り項数 $N_{C}$ が $L_{1}$ 境界の合 力 $P_{x} / X_{1}$ の分布に及ぼす影響を示している. 横軸が角度 $\theta$, 縦軸が $L_{1}$ 境界の合力 $P_{x} / X_{1}$ を表している. 今回の対 向集中荷重の場合， $P_{x} / X_{1}$ の厳密解は，以下のように与えられる.

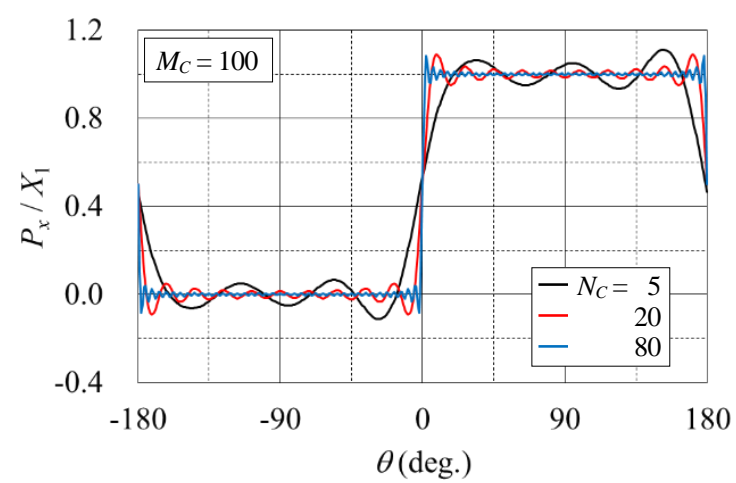

(a) Effect $N_{C}$ on $P_{x}$ distribution on $L_{1}$ boundary.

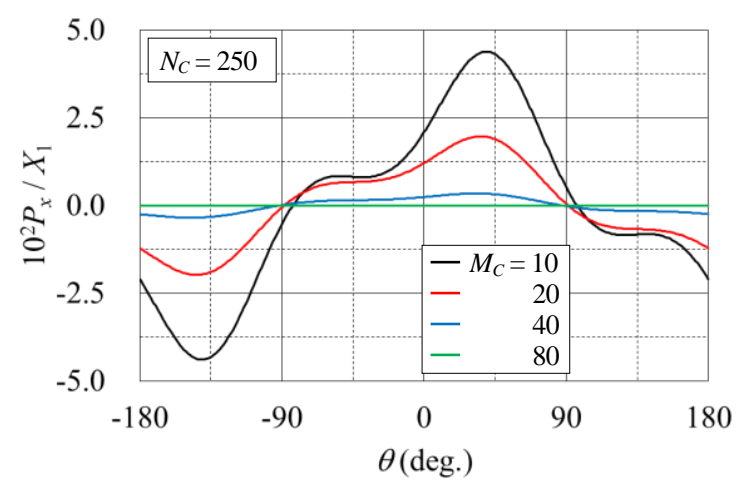

(b) Effect $M_{C}$ on $P_{x}$ distribution on $L_{2}$ boundary.

Fig. 9 Relation between accuracy of boundary condition for resultant stress $P_{x}$ and term number $N_{C}$ (or number of cycles $M_{C}$ ).

$$
\frac{P_{x}}{X_{1}}=\left\{\begin{array}{l}
1 \text { for } 0<\theta<180^{\circ}, \\
0 \text { for }-180^{\circ}<\theta<0 .
\end{array}\right.
$$

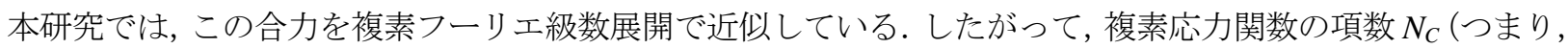
複素フーリエ級数の項数) を増すことにより, 式 (46) の㛜密解に漸近していることが確認できる. なお，式 (46) 
Tane, Sasaki, Tabuchi, Uchida and Hamano, Transactions of the JSME (in Japanese), Vol.82, No.835 (2016)

は階段関数を表しており，角度領域の両端で不連続点を持つため，ギブス現象の影響を受ける．しかし，その影 響は極めて限定的で，実用上の問題は小さいと考えられる.

図 9 (b) は, 図 9 (a) と同じ問題について, 先の項数 $N_{C}=250$ に設定した上で, 収束計算回数 $M_{C}=10,20,40$ および 80 と変えたとき, 内側境界 $L_{2}$ の合力 $P_{x} / X_{1}$ の分布を求めたものである. 題意より, 厳密解は $P_{x} / X_{1}=0$ となるが, $M_{C}=80$ とすれば, この厳密解とほぼ同じ結果が得られ, 問題ないことが確認できた.

一方， $M_{C}=10,20$ および 40 では， $\theta=35 \sim 40^{\circ}$ の辺りで誤差の最大值を生じ，その大きさは $X_{1}$ 比でそれぞれ 4.39，1.97 および $0.35 \% て ゙ あ っ た 。 つ ま り ， M_{C}$ が小さいほど境界条件の精度が低下寸ることを表している．これ は, この程度の収束計算回数では, 3.3 節(5に書かれているように仮想境界上の合力が十分小さくなっていないこ とを示すものである.

以上の検討により, 以下では打切り項数 $N_{C}=250$ および収束計算回数 $M_{C}=80$ に設定，境界条件の精度に問題 がないことを確認しながら計算を行った。

\section{$4 \cdot 3$ 静圧が作用する場合の計算例}

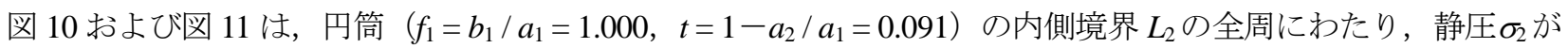
作用する（図 7 および式（44）において $\omega=\pi \mathrm{rad}$ とする）場合について，応力および変位を計算した一例を示し ている.

はじめに図 10 (a) は円筒断面に生じる極座標系の応力成分 $\sigma_{r}$ (黒色)， $\sigma_{\theta}$ (赤色) および $\tau_{r}$ （青色）の半径方 向（厚さ方向）の分布を表している. この図において，マーカーは $x-y$ 平面内で等方性を示す場合 $\left(E_{x}=E_{1}, E_{y}=\right.$ $\left.E_{3}, E_{z}=E_{2}\right)$ について，以下に示寸式（森口，1957）による算定結果を示している.

$$
\begin{aligned}
\sigma_{r} & =-\left(\frac{b^{2}}{a^{2}-b^{2}}-\frac{a^{2} b^{2}}{a^{2}-b^{2}} \frac{1}{r^{2}}\right) \sigma_{2}, \\
\sigma_{\theta} & =-\left(\frac{b^{2}}{a^{2}-b^{2}}+\frac{a^{2} b^{2}}{a^{2}-b^{2}} \frac{1}{r^{2}}\right) \sigma_{2}, \\
\tau_{r \theta} & =0
\end{aligned}
$$

ここに， $a, b$ は円筒の外半径および内半径である.

一方，このマーカーに重なっている実線は $x-y$ 平面内で直交異方性を示寸場合 $\left(E_{x}=E_{1}, E_{y}=E_{2}, E_{z}=E_{3}\right), つ$ まり，等方性のときの弾性主軸 $E_{2}$ および $E_{3}$ を， $x$ 軸まわりに $\alpha=90 \mathrm{deg}$. 回転させた場合に相当しており，本論文 の解法により求めた結果を示している.

つぎに, 図 10 (b) は円筒断面の変形の様子を表している. 変形の様子を分かりやすくするために, 変形後の 断面については実際の変形量を 10 倍して表示した. 赤の破線が等方性の場合, 青の一点鎖線が直交異方性の場合

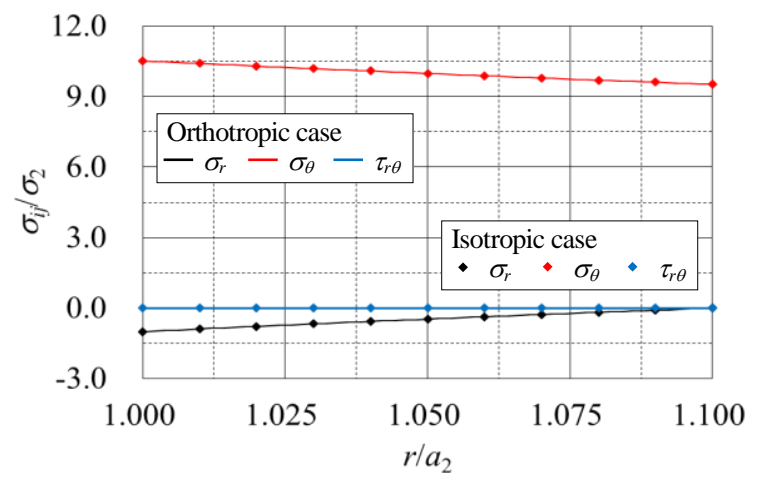

(a) Stress distribution along thickness direction.

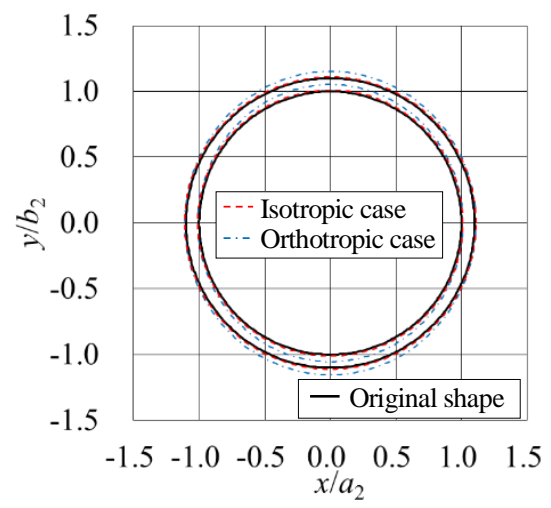

(b) Deformation diagram.

Fig. 10 Stress distribution and deformation diagram for the case of the orthotropic cylinder $\left(E_{x}=E_{1}, E_{y}=E_{2}, E_{z}=E_{3}\right)$, which is subjected to inner pressure $\sigma_{2}$ shown in Fig. $8\left(f_{1}=b_{1} / a_{1}=1.000, t=1-a_{2} / a_{1}=0.091, M_{C}=80, N_{C}=250\right)$. 
の変形後断面を表している. これら 2 つ場合では, $x$ 軸方向 (水平方向) の縦弾性係数はともに $E_{x}=E_{1}$ であり, この方向の伸び縮みのしや寸さは同じである.

しかしながら， $y$ 軸方向（鉛直方向）の縦弾性係数が等方性のとき $E_{y}=E_{3}\left(=E_{1}\right)$ であるのに対し，直交異方 性のとき $E_{y}=E_{2}\left(=E_{1} / 5\right)$ に設定されているため, 円筒断面の上下部において, 直交異方性の場合がより鉛直方 向に変形している様子を表している.

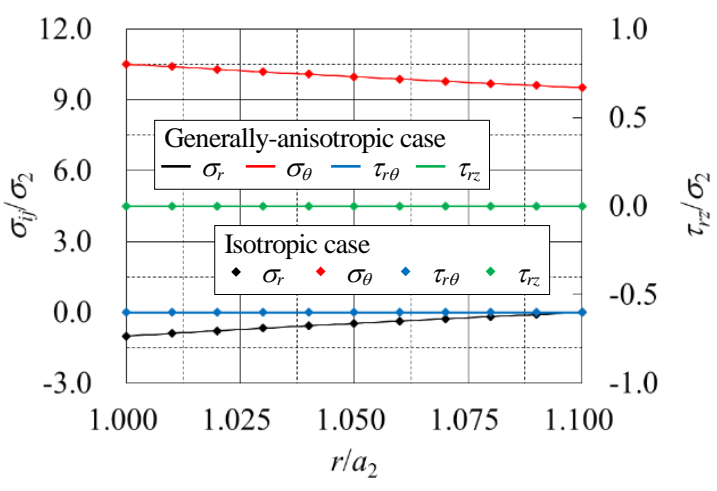

(a) Stress distribution along thickness direction.
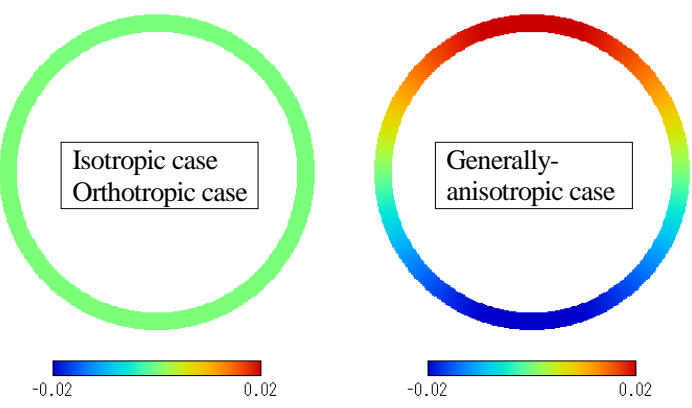

(b) Contour diagram for the antiplane displacement $10 w /\left(\sigma_{2} a_{2}\right)$.

Fig. 11 Coupling effect of antiplane shear stress / displacement components due to inner pressure $\sigma_{2}$, for the case of the directions of principal axes of elasticity $E_{1}, E_{2}$ and $E_{3}$ are coincide with $x$-axis, $y=z$ and $y=-z$, respectively $\left(f_{1}=b_{1} /\right.$ $\left.a_{1}=1.000, t=1-a_{2} / a_{1}=0.091, M_{C}=80, N_{C}=250\right)$.

図 11 は, 面内問題と面外せん断問題の相互干渉(連成)の起こる一般的な異方性材料について検討したもので, 弾性主軸 $E_{2}$ および $E_{3}$ をそれぞれ $y=z$ および $y=-z$ の方向に向けた場合の計算例である.

図 11 （a）は図 10 (a) と同様に, 円筒半径方向の応力の分布を表した. 連成の程度を見るために，面外せん断 応力 $\tau_{r z}$ の分布を, 右縦軸を使って新たに表示したが，明示のとおり $\tau_{r z}=0$ であった．もう一つの面外せん断応力 についても $\tau_{2}=0$ となることを確認しており，結果として面外せん断応力は連成しないことが分かった.

そして，その他の応力成分については，等方性の場合の森口の解に完全に一致していることが示されている. 以上，直交異方性の場合の図 10 (a)，一般的な異方性の場合の図 11 (a) より，円筒に内圧が均等に作用寸る場 合, これら材料異方性は応力分布に影響を与えないことが確認された.

図 11 （b） は円筒断面の $z$ 軸方向変位 $w$ の分布を示している．左側が等方性あるいは直交異方性（図 10）を示 寸場合に相当し，これらでは面内問題と面外せん断問題の分離により，全断面で $w=0$ であることを示している. 右側が一般的な異方性を示寸場合の分布を表しており, 円筒の中心を通る水平軸（ $x$ 軸）を境に, 上側が紙面手 前方向に，下側が紙面奥行き方向に変位し，かつ，この変位量は水平軸から離れるにつれて大きくなることを示 している．このように，円筒断面の鉛直方向に $w$ が分布していることにより，連成の影響が認められる.

\section{4 -4 対向集中荷重が作用する場合の計算例}

図 12 および図 13 は，長さ $2 a_{2}$ のクラック（円柱と中心を同じくする $x$ 軸上のクラック）を有する直径 $2 a_{1}$ の円 柱に対向圧縮集中荷重 $X_{1}(<0)$ が作用寸る場合（図 8）についての計算例で，コンクリートや岩盤など，ぜい性 材料の引張強度算定法として用いられる割裂試験を想定したものである.

はじめに, 図 12 は $x$ 軸（載荷軸）上の応力分布を示したもので, 実線が垂直応力 $\sigma_{x}$, 波線が垂直応力 $\sigma_{y}$ を表し ている．ここでは，円柱の直径 $2 a_{1}$ を固定して，クラック長を $a_{2} / a_{1}=0.20$ （赤色）, 0.40 （青色）, 0.60（緑色） の 3 種類に変化させた場合について, 本論文の解を用いて計算を行った. なお, クラックの高さは理論上 $b_{2}=0$ であるが，便宜的に $b_{2} / a_{1}=0.001$ と設定して近似解を求めた．また，図中には，クラックが存在しない場合，つ まり, $a_{2} / a_{1}=0.00$ の場合の結果（黒色）も示した. この結果は, 著者らが以前に報告した中実円柱の解（種他, 2012）によるものである.

図 12 (a) は, $x-y$ 平面（断面）内で等方性を示寸場合 $\left(E_{x}=E_{1}, E_{y}=E_{3}, E_{z}=E_{2}\right)$ の分布図である. $a_{2} / a_{1}=0.00$ の解は，等方性弾性を仮定して求められた解（森口，1957）に完全に一致寸る. 
Tane, Sasaki, Tabuchi, Uchida and Hamano, Transactions of the JSME (in Japanese), Vol.82, No.835 (2016)

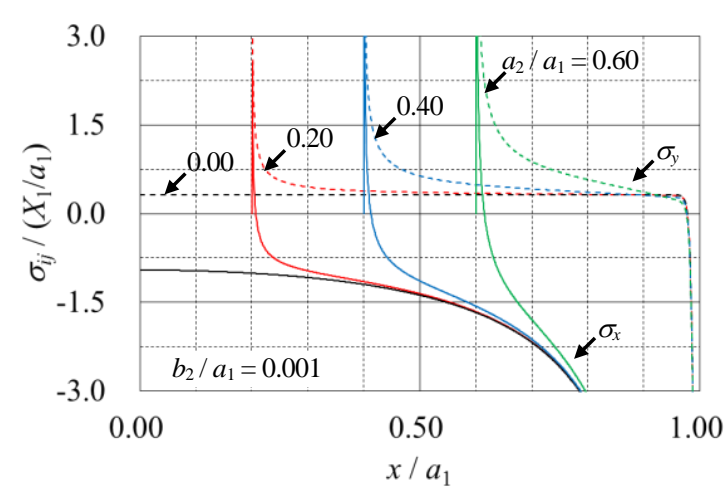

(a) For the case of the isotropic material. $\left(E_{x}=E_{1}, E_{y}=E_{3}, E_{z}=E_{2}\right)$

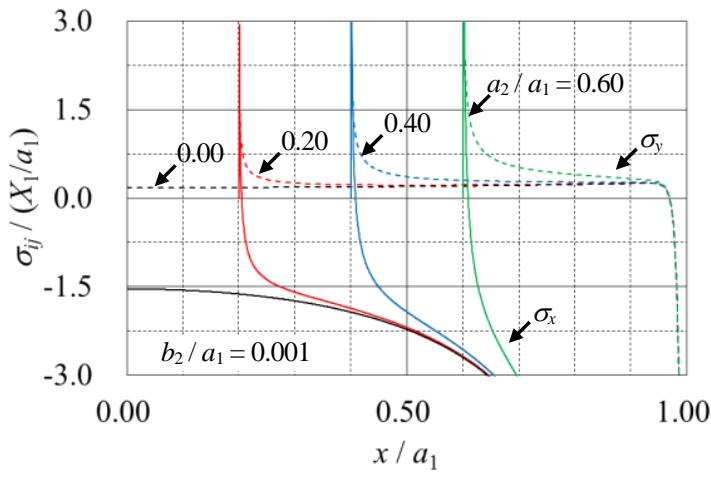

(b) For the case of the orthotropic material. $\left(E_{x}=E_{1}, E_{y}=E_{2}, E_{z}=E_{3}\right)$

Fig. 12 Stress distribution on the $x$ axis of the cylinder (with a crack) subjected splitting load $X_{1}\left(f_{1}=b_{1} / a_{1}=1.000\right.$, $\left.M_{C}=80, N_{C}=250\right)$.

$$
\begin{aligned}
\sigma_{x} & =-\frac{X_{1}}{\pi a}\left[1-\frac{4}{\left\{1-(x / a)^{2}\right\}}\right] \\
\sigma_{y} & =-\frac{X_{1}}{\pi a}
\end{aligned}
$$

ここに，aは円柱の半径である. 図 12 (a) から, クラックが存在するとその先端において $\sigma_{y}$ か応力特異性を生じ ていることが分かる． $\sigma_{x}$ は先端に近づくにつれ圧縮応力から引張応力に遷移し，その值も大きくなるが，クラッ ク先端では $\sigma_{x}=0$ の境界条件を満たしている. また, 両応力ともに先端から円柱半径の $1 / 3$ 程度離れた辺りから, 中実円柱の解に収束しており，クラックの影響を受けていないことが分かった.

図 12 (b) は，直交異方性を示古場合 $\left(E_{x}=E_{1}, E_{y}=E_{2}, E_{z}=E_{3}\right)$ の同様の分布図である. 両応力 $\sigma_{x}, \sigma_{y}$ の分布 について，図 12 (a) の等方性の場合と同様な傾向が見られる.ただし，鉛直軸（ $y$ 軸）方向の縦弾性係数 $E_{2}$ が 水平軸 $\left(x\right.$ 軸) 方向の縦弾性係数 $E_{1}$ より小さいため, クラック先端近傍を除き, 水平方向の応力分担がより大き くなっている.

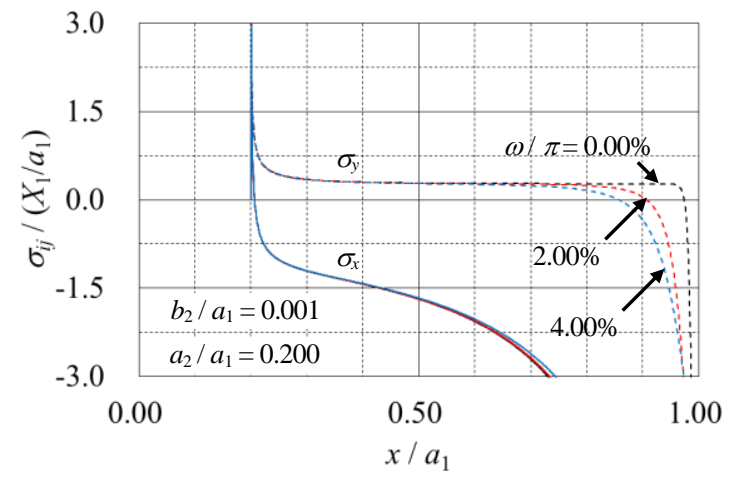

(a) In-plane stress $\sigma_{x}$ and $\sigma_{y}$.

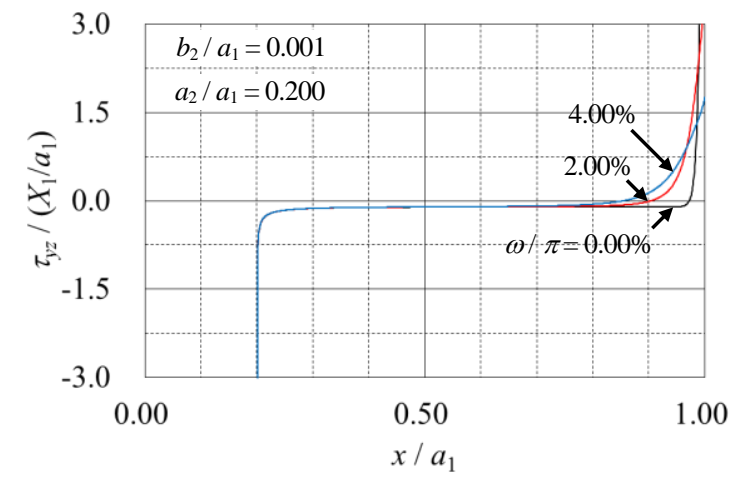

(b) Antiplane shear stress $\tau_{y z}$.

Fig. 13 Stress distribution on the $x$ axis of the cylinder (with a crack) subjected splitting load $X_{1}$ or distributed load $\sigma_{1}\left(f_{1}=b_{1} /\right.$ $\left.a_{1}=1.000, M_{C}=80, N_{C}=250\right)$.

続いて, 図 13 は $a_{2} / a_{1}=0.20, b_{2} / a_{1}=0.001$ のクラックを有する一般的な異方性 $(4 \cdot 3$ 節の図 11 と同じ $)$ を示 寸円柱が，図 12 と同様に対向圧縮集中荷重 $X_{1}(<0)$ を受ける場合について， $x$ 軸上の応力分布を求めたもので ある. 図 13 (a) が面内応力 $\sigma_{x}, \sigma_{y}$ の分布，図 13 (b) が面外せん断応力 $\tau_{y z}$ の分布をそれぞれ表している. $3 ・ 4$ 節 の計算例では見られなかった，面外せん断応力の連成が確認できる. その程度は $x / a_{1}=0.50$ において $\sigma_{y}$ 比 $38 \%$ 程度と比較的大きい.

この図には, 図 8 の集中荷重 $X_{1}$ を図 7 の静圧 $\sigma_{2}$ で近似した結果も示してある. 領域角 $\omega$ を指定すると, 静圧 $\sigma_{2}$ 
は次式によって求めることができる.

$$
\sigma_{j}=\frac{X_{j}}{2 a_{j} \sin (\omega / 2)} .
$$

図 13 には, 領域角を $\omega / \pi=2.00,4.00 \%$ となるように設定した計算例が示されている。 $\sigma_{y}$ および $\tau_{y z}$ は $0.40<x / a_{1}$ < 0.80 の範囲でほぼ一定となり, 集中荷重の場合と静圧近似の場合で差は見られなかった. 静圧近似の影響は,

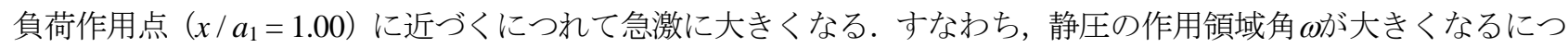
れて, 応力の急変点が円柱の中心側に移動していることが分かる. 以上により, 静圧および対向圧縮荷重の解の 双方が正しく導かれていると考えられる。

\section{5. 結}

本論文では，一般的な異方性弾性材料からなるだ円筒に対し，その内外両境界に任意の外力が作用する場合の 解を 2 次元弾性理論により導き，幾つかの数值計算例を示してきた．等方性弹性材料についてこの種の問題を解 いた論文も存在する（川久保，平島，1997）が，両境界を同心円群に写像変換して解くその方法から，内外境界 が焦点を同じく寸るだ円についての場合のみ，解を求めることが可能であった.

一般的な異方性弾性材料の場合，例え両境界が焦点を同じく寸るだ円であっても，例を示したように写像変換 後に同心円群にならない. そこで，（拘束解除法と呼ばれる）2 モデルの解を用いた収束計算手法により，近似的 に解を導いた．したがって，4・4節で示したように，だ円筒の 2 境界が焦点を異にする場合についても，解を得 られることが本論文の特徴の 1 つである.

なお, $x-y$ 平面内でのみ弾性主軸が傾斜する異方性弾性材料の特別な場合については, 既に解が導かれている(堤， 平島，1997）。しかし，彼らの成果では，面内問題と面外せん断問題が相互影響（連成）する一般的な異方性弾性 材料について, 応力・変位の検討を行うことはできない. 本論文は, 対象をこの一般的な異方性弾性材料に定め たもので， 4 ・3 節などにおいて，連成の影響について計算例を示した．また，先の論文ではそもそも外力が面内 荷重に限定されているのに対し，本論文では面外せん断荷重に対する解も求めることができる点を2つ目の特徵 として挙げることができる. この数值計算例については，今後改めて示していく予定である.

解の妥当性については，等方性弾性材料を対象とした研究や，著者らがだ円柱を対象に導いた解などとの比較 を通じて検証した。また，内外両境界における力の境界条件などにも注意を払ったほか，有限要素法による結果 ともよく一致していることをすでに確認した.

冒頭で述べたように，一般的な異方性弾性材料に対する解は，圧電性を有する異方性弾性材料の特別な場合や 一般的な異方性粘弾性材料の解へと応用が可能であるため, これらの解を求めることなどが今後の課題となって くる. また，4・4節ではクラックを有する円柱についての計算を行ったが，クラック先端における応力拡大係数 などについても今後評価し, 報告予定である.

\section{文献}

川久保昌平, 堤隆, 平島健一, 任意分布の荷重を受ける異方性だ円板の応力, 変位場, 日本機械学会論文集 A 編, Vol. 62, No. 599 (1996), pp. 1626-1633.

川久保昌平, 平島健一, 複素応力関数を用いただ円輪問題の応力・変位解析, 材料, Vol. 46, No. 9 (1997), pp. 1011-1016.

Lekhnitskii, S. G., Anisotropic Plates (1958), p. 534, Gordon and Breach Science Publishers.

Lekhnitskii, S. G., Theory of elasticity of an anisotropic elastic body (1964), p. 404, Holden-day Inc.

林為人, 中村敏明, 高橋学, 稲田花崗岩の熱特性, 超音波速度, 強度および変形特性の異方性, 応用地質, Vol. 44,

No. 3 (2003), pp. 175-187.

森口繁一, 2 次元弹性論 (1957), p. 77, 岩波書店.

中曽根祐司, 異方性材料の弾性論（2014）, pp.6-8, コロナ社.

中山岳彦, 平島健一, 鈴木拓雄, 極異方性弾性体の幾つかの基本解の誘導および解析, 材料, Vol. 52, No. 4 (2003), pp. 400-406. 
奈良禎太，金子勝比古，花崗岩の異方弾性定数の評価法に関する研究，資源と素材，Vol. 119， No. 6 (2003), pp. 396-402.

Nemeth, M. P. and Schultz, M. R., The exact solution for linear thermoelastic axisymmetric deformations of generally laminated circular cylindrical shells, NASA TP-2012-217342 (2012).

丹羽義次, 小林昭一, 平島健一, 三次元直交異方性弾性岩盤内の円形坑道周辺の応力および変形, 土木学会論文 報告集，Vol. 1970， No.173 (1970a)，pp.7-17.

丹羽義次, 小林昭一, 平島健一, 三次元異方性弾性岩盤内に開削された任意形状の坑道の周辺における応力状態, 材料, Vol. 19, No. 197 (1970b), pp. 138-144.

桜井春輔，異方性粘弾性体に対するレオロジー方程式とその応用，材料，Vol. 20， No. 209 (1971), pp. 136-142.

佐々木徹, 鈴木拓雄, 種健, 平島健一, 面内荷重下における多層楕円形介在物を有寸る異方性圧電弹性体の解析, 日本機械学会論文集 A 編，Vol. 71，No. 707（2005），pp. 1073-1080.

志村穣, 田中純夫, 平島健一, 能登谷久公, 自由境界および固定境界条件下における半無限問題の解析解 (等方 性・異方性弾性体の面外せ几断問題)，日本機械学会論文集 A 編，Vol. 68，No.673 (2002)，pp. 1401-1406.

高野敦, 面外せん断変形を考慮した一般異方性円筒殼の軸圧縮・㸚じりおよび複合荷重における解, 日本機械学 会論文集 A 編，Vol. 79， No. 806 （2013），pp. 1471-1485.

高野敦, 一般異方性円筒殼の軸圧縮・㸚じりおよび複合荷重に対する閉じた解, 日本機械学会論文集, Vol. 80, No. 812 (2014), DOI: 10.1299/transjsme.2014smm0085.

高野昇, 池田直樹, 平島健一, 能登谷久公, 基本荷重下でのだ円孔を有する異方性の平板曲げ問題の解析解と数 值計算例，日本機械学会論文集 A 編，Vol. 67，No.660（2001），pp. 1312-1317.

田中純夫，平島健一，Anis JEDIDI，広瀬幸雄，す心゙りを含む各種の境界条件下での半無限板問題の解析解につい て(第 2 報, 異方性弾性体の面内問題の場合), 日本機械学会論文集 A 編, Vol. 58, No. 553 (1992), pp. 1662-1669.

田中純夫, 平島健一, 広瀬幸雄, Toshio MURA, すべりを含む各種の境界条件下での半無限板問題の解析解につ いて（第 4 報，異方性弾性平板の曲げ問題の場合），日本機械学会論文集 A 編，Vol. 59, No. 559 (1993), pp. 792-799.

種健，平島健一，浜野浩幹，層状楕円形介在物を有する異方性弾性体の解析および応力拡大係数の計算，日本機 械学会論文集 A 編, Vol. 70, No. 698 (2004)，pp. 1412-1419.

種健, 平島健一, 浜野浩幹, 面外垂直応力下での多層だ円形介在物を有する 3 次元異方性弾性体の解析および数 值計算, 材料, Vol. 54, No. 3 (2005), pp. 326-332.

種健，内田武，佐々木徹，木村清和，側面に任意荷重を受ける異方性だ円柱の解析，材料，Vol. 61, No. 10 (2012), pp. 845-851.

堤隆，平島健一，拘束解除法を用いた直交異方性弾性体の楕円リングの応力，変位の解析，日本機械学会論文集 A 編, Vol. 63, No. 615 (1997), pp. 2411-2416.

\section{References}

Kawakubo, S., Tsutsumi, T. and Hirashima, K., Stress and displacement fields for an anisotropic elliptical disk subjected to arbitrary loads at the boundary, Transactions of the Japan Society of Mechanical Engineers, Series A, Vol. 62, No. 599 (1996), pp. 1626-1633 (in Japanese).

Kawakubo, S. and Hirashima, K., Analysis of elliptical ring by using Laurent series expansion of complex stress functions, Journal of the Society of Materials Science, Japan, Vol. 46, No. 9 (1997), pp. 1011-1016 (in Japanese).

Lekhnitskii, S. G., Anisotropic Plates (1958), p. 534, Gordon and Breach Science Publishers.

Lekhnitskii, S. G., Theory of elasticity of an anisotropic elastic body (1964), 404pp., Holden-day Inc.

Lin, W., Nakamura, T. and Takahashi, M., Anisotropy of thermal property, ultrasonic wave velocity, strength property and deformability in Inada granite, Journal of Japan Society of Engineering Geology, Vol. 44, No. 3 (2003), pp. 175-187 (in Japanese).

Moriguchi, S., Two dimensional elastic theory (1957), p. 77, Iwanami Shoten, Publishers (in Japanese).

Nakasone, Y., Theory of anisotropic materials (2014), pp.6-8, CORONA PUBLISHING CO., LTD (in Japanese).

Nakayama, T., Hirashima, K. and Suzuki, T., Fundamental solutions for cylindrically anisotropic elastic medium, Journal of the Society of Materials Science, Japan, Vol. 52, No. 4 (2003), pp. 400-406 (in Japanese).

Nara, T. and Kaneko, K., Evaluation of the elastic constants of granite, Shigen-to-Sozai, Vol. 119, No. 6 (2003), pp. 396-402 (in Japanese). 
Nemeth, M. P. and Schultz, M. R., The exact solution for linear thermoelastic axisymmetric deformations of generally laminated circular cylindrical shells, NASA TP-2012-217342 (2012).

Niwa, Y., Kobayashi, S. and Hirashima, K., Stresses and deformations around a circular tunnel excavated in orthotropic elastic ground under a three-dimensional stress state, Proceedings of the Japan Society of Civil Engineers, Vol. 1970, No. 173 (1970a), pp. 7-17 (in Japanese).

Niwa, Y., Kobayashi, S. and Hirashima, K., Stresses around a tunnel with an arbitrary cross section excavated in anisotropic elastic ground, Journal of the Society of Materials Science, Japan, Vol. 19, No. 197 (1970b), pp. 138-144 (in Japanese).

Sakurai, S., Rheological equation of anisotropic viscoelastic material and its application to problems pertinent to rock mechanics, Journal of the Society of Materials Science, Japan, Vol. 20, No. 209 (1971), pp. 136-142 (in Japanese).

Sasaki, T., Suzuki, T., Tane, T. and Hirashima, K., Analysis of anisotropic piezoelectric materials with multilayered elliptical inclusion under in-plane loadings, Transactions of the Japan Society of Mechanical Engineers, Series A, Vol. 71, No. 707 (2005), pp. 1073-1080 (in Japanese).

Shimura, J., Tanaka, S. and Hirashima, K., Analytical solutions for semi-infinite problems under free and fixed surface boundary conditions (Cases of anti-plane problems for isotropic and anisotropic elastic bodies), Transactions of the Japan Society of Mechanical Engineers, Series A, Vol. 68, No. 673 (2002), pp. 1401-1406 (in Japanese).

Takano, A., Thin and moderately thick anisotropic cylinders under torsion, axial compression and combined load, Transactions of the Japan Society of Mechanical Engineers, Series A, Vol. 79, No. 806 (2013), pp. 1471-1485 (in Japanese).

Takano, A., Closed-form solutions of thin anisotropic cylinders under torsion, axial compression and combined load, Transactions of the Japan Society of Mechanical Engineers, Vol. 80, No. 812 (2014), DOI: 10.1299/transjsme.2014smm 0085 (in Japanese).

Takano, N., Ikeda, N., Hirashima, K. and Notoya, K., Analytical solutions and numerical examples for anisotropic bending problems with elliptic hole or rigid inclusion under singular loads, Transactions of the Japan Society of Mechanical Engineers, Series A, Vol. 67, No. 660 (2001), pp. 1312-1317 (in Japanese).

Tanaka, S., Hirashima, K., Jedidi, A. and Hirose, Y., Analytical solutions for semi-infinite problems under several boundaries including sliding conditions (2nd Report, Case of in-plane problems for anisotropic elastic body), Transactions of the Japan Society of Mechanical Engineers, Series A, Vol. 58, No. 553 (1992), pp. 1662-1669 (in Japanese).

Tanaka, S., Hirashima, K., Hirose, Y. and Mura, T., Analytical solutions for semi-infinite problems under several boundaries including sliding conditions (4th Report, Case of bending problems for anisotropic elastic plate), Transactions of the Japan Society of Mechanical Engineers, Series A, Vol. 59, No. 559 (1993), pp. $792-799$ (in Japanese).

Tane, T., Hirashima, K. and Hamano, H., Analysis for anisotropic medium with multi-layered elliptic inclusion and its stress intensity factors, Transactions of the Japan Society of Mechanical Engineers, Series A, Vol. 70, No. 698 (2004), pp. 1412-1419 (in Japanese).

Tane, T., Hirashima, K. and Hamano, H., Analysis for three-dimensional anisotropic elastic medium with multi-layered elliptic inclusions under out-of-plane normal stress, Journal of the Society of Materials Science, Japan, Vol. 54, No. 3 (2005), pp. 326-332 (in Japanese).

Tane, T., Uchida, T., Sasaki, T. and Kimura, K., Analytical solutions of anisotropic body bounded by an elliptical surface subjected to arbitrary loads, Journal of the Society of Materials Science, Japan, Vol. 61, No. 10 (2012), pp. 845-851 (in Japanese).

Tsutsumi, T. and Hirashima, K., Analysis of anisotropic elliptic ring by using constraint release technique, Transactions of the Japan Society of Mechanical Engineers, Series A, Vol. 63, No. 615 (1997), pp. 2411-2416 (in Japanese). 